\title{
Elvesztett illúziók - reformközgazdászok a rendszerváltásban
}

Harminc évvel ezelőtt sokunkban élt három egymással összefüggő hit: a demokráciára épülö liberális kapitalizmus jól müködő rendszer, ami megfelelö (szak)politikai lépéssorozattal Magyarországon is bevezethető, és kialakításában az értelmiség, a tudomány, köztük a közgazdászszakma is fontos szerepet játszik. Amellett fogok érvelni, hogy azoknak a kimondatlan, de axiómaként kezelt tételeknek a többsége, amelyek írásainkat és magatartásunkat is meghatározták, illúziónak bizonyult. Az erről nemrégiben elindult vitához annak közelebbi vizsgálatával szeretnék csatlakozni, hogy mi is volt az erős hit alapja, és mi rendíthette meg azt. Ezeket a kérdéseket nemcsak azért érdemes feltenni, hogy reálisabban mérhessük fel, hogy - szélesebb vagy szükebb közösségünk és mi magunk - meddig jutottunk, hanem azért is, hogy a választási lehetőségeket világosabban megfogalmazhassuk.* Journal of Economic Literature (JEL) kód: A11, A14.

„Nem az új gondolatok megértése nehéz, hanem a régiektől való megszabadulás.” John Maynard Keynes ${ }^{1}$

„Úgy gondoltuk, abban reménykedtünk, hogy szabad, nyugatias, liberális demokrácia, jogállam alakul ki, magántulajdonon és versenyen alapuló, észszerűen szabályozott, felzárkózó gazdaság válik meghatározóvá, és mindez olyan társadalompolitikával kombinálódik, amely védi a leszakadókat, a szegényeket, felkarolja a kisebbségeket, szolidáris velük - és persze a sajtó is szabad. Ám nem így történt” - foglalta össze nemrégiben Surányi György a liberális irányultságú reformértelmiség reményeit és csalódásait (Surányi [2019] 82. o.). A többes szám egy csapatra utal, amely

* Köszönettel tartozom Laki Mihálynak, Mihályi Péternek, Schlett Istvánnak, Surányi Györgynek, Szegvári Péternek és Várhegyi Évának a kézirat első változatához füzött megjegyzésekért.

${ }^{1}$ Keynes [1936/1965] 11. o.

Voszka Éva, Szegedi Tudományegyetem Pénzügyek és Nemzetközi Gazdasági Kapcsolatok Intézete,

Pénzügykutató Zrt. (e-mail: voszka.eva@eco-u.szeged.hu). A kézirat első változata 2019. október 27-én érkezett szerkesztőségünkbe.

DOI: http://dx.doi.org/10.18414/KSZ.2019.12.1284 
a rendszerváltás idején jórészt a középgenerációhoz tartozó kutatókból és az államapparátusban dolgozó jogászokból, közgazdászokból állt, de kapcsolódtak hozzájuk szociológusok és a vitákban, a nézetek terjesztésében aktív újságírók is. A „liberális” jelző nem pártkötődésre utal, hanem azokra, akik a piac meghatározó szerepében, a minimális államban hittek, legalábbis a gazdaság területén. Ezért sokszor nevezték őket piaci fundamentalistáknak vagy - egyik alapértékükre hivatkozva - a modernizációs paradigma híveinek is. ${ }^{2}$ A szociológiai előzményekre is utalva a csoportot, amelynek előfeltevéseiről és gondolkodásmódjáról, sikereiről és kudarcairól szól ez az esszé, röviden reformközgazdászoknak nevezem.

Az indító idézetben szereplő „,remény” voltaképpen két elemből állt: az egyik a liberális kapitalizmusba, a másik az annak hazai bevezethetőségébe vetett hit. Nevezzük ezeket röviden rendszerillúziónak és applikációs illúziónak! Hozzájuk társul a szerepillúzió - az értelmiség, a közgazdászszakma feladata, hivatása ebben a folyamatban. E háromféle erős hit elméleti és tapasztalati előfeltételeit vizsgálom meg közelebbről, majd a működését a privatizáció példáján, végül a túllépést segítő tényezőket és a lehetséges választási irányokat vázolom fel. A megközelítés nem elmélettörténeti, ${ }^{3}$ inkább szociológiai.

Bár most csak a magyarországi folyamatokról lesz szó, nem gondolom, hogy a leírtak magyar sajátosságok volnának. A válságos körülmények - mint ahogy próbálom majd bemutatni - mindig felértékelték a (társadalom)tudományokhoz kapcsolódó értelmiség szerepét. Sok példát tudunk mondani az elmúlt évtizedekből a kutatás, az akadémiai szféra, valamint a politika szoros kapcsolatára és képviselöik ingázására a két terület között világszerte. A kelet-közép-európai rendszerváltások pedig valószínűleg csak felerősítették ezt az általános jelenséget minden érintett országban. Az állítás alátámasztásához alapos nemzetközi összehasonlításra volna szükség, amire most nem tudok vállalkozni, mint ahogy arra sem, hogy a hazai terepről átfogó képet adjak szakfolyóiratok, a korabeli sajtó, a parlamenti viták és politikai dokumentumok feldolgozásával. A gondolatmenetbe beépítettem idézeteket néhány reprezentatív szereplőtől - miközben sok fontos csoporttag kimaradt -, de ezek inkább csak illusztrációk, mint bizonyítékok.

Lehet, hogy az elemzés néhol szubjektívnek tűnik majd, noha bírálat vagy mentegetés helyett résztvevőként, de most már a külső megfigyelő pozíciójából értékmentes leírásra törekedtem, egészen a lehetséges alternatívák felvázolásáig, amelyek értékválasztásokat tükröznek.

\footnotetext{
${ }^{2}$ Sebők [2019] indoklása szerint ez utóbbi, tágabb keret teremtette meg a konszenzust a „domináns elitcsoport” két része, a liberálisok és az „utódpárti” szocialisták között (109. o.), ez volt a „közös szellemi minimum" (120. o.) a név szerint is felsorolt résztvevők számára (164-165. o.). A szerző alkalmazza rájuk az „organikus értelmiség” kategóriát is, amely „képes az új idők új ideológiáját a közvélemény befolyásolásával hirdetni” (162. o.), személyes és intézményi hatalmi pozíciókat is építeni.

Az általam itt lazán körvonalazott kategória a szakmák szempontjából szélesebb, mint a Szalai [1992/1994] által definiált csoport, és szociológiai értelemben tágabb az „új technokráciánál” (Szalai 1993/1994).

${ }^{3}$ Erre több kísérlet is történt, különbözö kérdésfeltevésekkel. Kovács János Mátyás például a rendszerváltás hatását vizsgálta a hazai közgazdaság-tudományra (Kovács [1996]), Csaba László pedig azt, hogy mivel járult hozzá az átmenettan, a tranzitológia a világ gazdaságtudományához (Csaba [2014a]).
} 


\section{Gyökerek és előfeltételek}

Az illúziók sokféle hazai és nemzetközi körülménnyel, elméleti és szociológiai keretfeltétellel magyarázhatók. Kezdjük a szálak felfejtését két olyan kiindulóponttal, amelyekben az 1980-as évek végén általános volt a szakmai, társadalmi sőt politikai egyetértés! Magyarországon súlyos és átfogó társadalmi-gazdasági válság van, és a megoldás feltétele a korábbi rendszer gyökeres átalakítása. ${ }^{4}$

A HELYZET • Az átfogó társadalmi-gazdasági válság máshol és máskor is kedvezett az eszmék és termelöik befolyásának. „Az emberek ma különösen türelmetlenül várnak a szokásosnál alaposabb diagnózisra” - írta Keynes az 1930-as években. - „Buzgón készülnek a kipróbálására, ha legalább hihetőnek tünik." (Keynes [1936/1965] 407. o.) Vagyis az elhúzódó válság felkelti a közvélemény - és tegyük hozzá, ezzel együtt a politikusok - igényét az új elméletekre, megnöveli a fogadókészséget. Ezt hangsúlyozta évtizedekkel később Milton Friedman is: „Csak egy folyamatban lévő vagy fenyegető válság vezet valódi változáshoz. Amikor a válság megjelenik, a meghozott intézkedések azoktól az eszméktől függnek, amelyek éppen elérhetők.” (Friedman [1962/1966] xiv. o.)

A 2008. évi válság kezelése kapcsán pedig Farrell-Quiggin [2017] kitünő elemzése is középpontba állítja az elméletek szerepét. Annak az álláspontnak a képviselői - írják -, akik szerint a válság teremti meg a politikai-társadalmi igényt az „eszmékre”, azt hangsúlyozzák, „hogyan találták szembe magukat a politikai döntéshozók rendkívüli bizonytalansággal és a közvélemény erős igényével arra, hogy tegyenek valamit” az összeomlás elkerülése érdekében. E felfogás alapkategóriája, a „töprengés”. „A politika nemcsak a hatalomból merít erőt, hanem a bizonytalanságból is - amikor az emberek kollektíven tünődnek azon, hogy mit tegyenek. [...] A kormányok nemcsak »hatalmat gyakorolnak«, hanem »töprengenek« is.” (Hugo Heclót idézi Hall [1993] 275. o.) Ekkor a szakértelem befolyása erős lehet.

Ilyen válságos helyzetnek tekinthető az 1980-as évek és az 1990-es évek fordulója, a felbomlásnak és egy új rendszer kiépítésének szélsőségesen bizonytalan időszaka is (lásd erről Bunce-Csanádi [1993]), amely megteremtette a keresletet, a társadalmi és politikai fogadókészséget az értelmiségi, ezen belül a közgazdasági eszmék iránt. A reformközgazdászok a rendszerváltás elött és azután is sokszor vizionáltak válságot - Magyarország gazdaságtörténetét ismerve erre persze többnyire meg is volt a jó okuk -, ami alkueszköznek is tekinthetö a mindenkori politikai vezetéssel folytatott diskurzusban (Szalai [1992/1994] 212. o.). Valószínüleg nem az eszmék felértékelödésére vonatkozó elméletek, hanem inkább saját tapasztalataik és megérzéseik vezérelték ambivalens vonzódásukat a krízishelyzetekhez. Mindenesetre a válság a szerepillúzió egyik fontos pillére. A válság ugyanakkor nemcsak az értelmiségi szerepet értékelte fel, hanem a kiinduló állapottól függően annak tartalmát is befolyásolta. Lássuk tehát a rendszerillúzió elméleti gyökereit!

\footnotetext{
${ }^{5}$ Az első szabad választáson induló pártok gazdasági programjait elemezve Laki [2000] ezeken a pontokon - sőt további fontos elemekben, például a nemzetközi gazdasági kapcsolatokban és a szerkezetváltás fö irányaiban - egyetértést talált. Ezeket a programokat döntően a később „holdudvarnak” nevezett, részben politikusi szerepet is vállaló értelmiségi/közgazdász szakértők állították össze.
} 
Az ÁTALAKULÁS IRÁNYA • Az irány meghatározásának elméleti alapjaihoz messziről is közelíthetünk, az általános társadalmi attitüdök ingadozása felől. A történelemben folyamatos az oszcilláció „az intenzív közösségi részvétel periódusai és az olyan szakaszok között, amikor szinte kizárólag az individuális haladás és az egyéni jólét céljaival foglalkoznak" - állítja Albert Hirschman, aki a fö oknak az egyéni csalódást tartja az egyik esetben sem tökéletes rendszerekben (Hirschman [1982] 3. o.). Felidézhetjük Polányi Károly hasonló leírását is, amely nem individuális, hanem társadalmi mozgásokkal, a romboló hatások elleni védekezési mechanizmusokkal, illetve a piacból származó előnyök elvesztéséből származó károk kompenzálásának törekvésével indokolta az ingadozást. Az önszabályozó piac pusztító hatásaival szemben „a társadalomnak óhatatlanul intézkednie kellett önmaga védelmében, de minden intézkedés rongálta a piaci önszabályozást, bomlasztotta az ipari életet, és így egy másik módon veszélyeztette a társadalmat" (Polányi [1946/2004] 26. o.), azaz ilyenkor az inga a másik irányba, a piac felszabadítása felé leng ki. (Bár a ronggyá olvasott Polányi-kötetekre hivatkozni éppen a reformközgazdászok körében nem volt ildomos. Ö ugyanis a gazdaság társadalmi beágyazottságáról írt, ${ }^{5}$ amit mi éppen meg akartunk haladni, kiszabadítva ezt a szférát a politika hatóköréből.)

A létező szocializmus „kollektív értékeinek”, a központilag vezérelt gazdaságnak a kritikája rég készen állt - elméletileg legfőképp Kornai János munkáiban (Kornai [1957], [1980], [1983]), de erről szóltak addigi empirikus kutatásaink, korábbi „reformerkedésünk” és az emberek hétköznapi tapasztalatai is. A szocializmus megjavításában, a piaci szocializmus lehetőségében ekkor már azok sem hittek, akik korábban a javaslatokat kidolgozták, ${ }^{6}$ de sokan nem voltak hívei a kapitalizmusnak sem. Jelentkezett a „baloldali” kapitalizmuskritika - legmarkánsabb képviselöje a reformközgazdászkörökből induló, de tölük már az 1990-es évek legelején eltávolodó Szalai Erzsébet -, és jelentkeztek bírálatok a másik oldalról is, de inkább tisztán politikai, mint szakmai terepen (Csurka István). Mindkét irányzatra jellemző, hogy kifejtett programjuk nem az 1980-as és az 1990-es évek fordulóján, hanem később kristályosodott ki. ${ }^{7}$ E nézeteket a föáram már csak ezért is a „nem komolyan vehetö" ${ }^{\prime \prime}$ kategóriába sorolta, érdemi vitára - például a bírálat egyes elemeinek megalapozottságáról - nem is került sor. Mindennek alapján csak egy szükebb körre, de a most vizsgált csoportra biztosan áll, amit Szelényi Iván írt: az értelmiség „1988-ra már feltétlenül leszámolt az

${ }^{5}$ „Az önszabályozó piac nem kevesebbet követel, mint a társadalom intézményes szétválasztását gazdasági és a politikai szférára" - írja Polányi [1946/2004] 104. o.), azt hangsúlyozva, hogy ez a szétválasztás a társadalom védekező mechanizmusai miatt lehetetlen.

${ }^{6}$ A piaci szocializmus elméleti vitáiról és kísérleteiről jó összefoglalót ad Kornai [1993] 496-529. o. „...ez az alapeszme kudarcot vallott” - szögezte le a rendszerváltás előtt (Kornai [1989] 27. o.). Ö maga egyébként soha nem volt ennek híve, a szocializmus reformálhatóságának lehetőségét korábban is elvetette, és 1956-1988 között nem is fogalmazott meg átfogó javaslatokat (Kornai [1989] 121. o.). Az 1980-as évek végéig így nem sorolható a reformközgazdászok közé, de később - legalábbis tevékenységének egy részével - igen. A megállapítások egy része azonban a tudományban betöltött különleges pozíciója miatt rá nem vonatkoztatható.

${ }^{7}$ Ezt nem cáfolja Sebők [2019] elemzése sem, aki a „jobboldali” kapitalizmuskritika fő vonalának a később megerősödő „matolcsyizmust” tartja - hivatkozásai mind későbbre datáltak.

${ }^{8}$ „....a bevett nézetek éppen akkor a legerősebbek, amikor a velük való egyetértés az alkalmasság és a komolyan vehetőség próbájává válik." (Krugman [1995] 36. o., idézi Sebők [2019] 191. o.) 
emberarcú szocializmusnak vagy a szocializmus és kapitalizmus között esetleges valamilyen harmadik útnak a gondolatával" (Szelényi [1995/1998] 28. o.), noha korábban ő maga is komolyan mérlegelte egyfajta harmadik út lehetőségét. „Ideáljává 1988-89-re a liberális kapitalista piacgazdaság vált” - tette még hozzá (uo.).

Ám a liberális irányt a kapitalizmust pártolók egy része sem fogadta el. A fó rivális az 1980-as évek legvégén a gazdaságpolitikában a Ludwig Erhardra, teoretikusan Wilhelm Röpkére hivatkozó szociális piacgazdaság lett, amit az Antallkormány programja meg is hirdetett. A reformközgazdászok hajlottak arra, hogy etatistának, „zsákutcás harmadik útnak” minősítsék ezt a megközelítést vetette szemükre Bod [2006] (23. o.). Márpedig az akkoriban valószínüleg kevesek által olvasott ${ }^{9}$ eredeti változat szerint „az erős, az éhes érdekcsoportok fölött álló állam" (Röpke [1943] 194. o.) legfontosabb szerepe - a szociális háló kiépítése mellett - a tiszta piaci verseny kereteinek kialakítása és fenntartása, nem az intervencionalista kiterjeszkedés. A rendszer nem a kommunizmus és a kapitalizmus közötti harmadik út, hanem az utóbbinak egy variánsa.

Noha elméletileg világos volt, hogy a kapitalizmusnak számos változata létezik - „a kapitalista rendszeren belül végtelen sok alternatíva van” (Kornai [1998] 34. o. $)^{10}-$, a "milyen kapitalizmust és milyen államot akarunk" kérdésének megvitatására sem került sor akkoriban tudományos terepen, racionális mérlegeléssel. ${ }^{11}$ Az álláspontok egyes elemei a politika színterein és a politikai pozíciókat tükrözö, kevesebb szakmai alaposságot igénylő közéleti fórumokon jelentek meg. Az érvek részletes kifejtése talán megmutatta volna, hogy bár a két berendezkedés között valóban vannak lényeges különbségek, a szociális piacgazdaság nem azonos az etatizmussal, a liberális kapitalizmus pedig a társadalmi szolidaritás semmibevételével. ${ }^{12}$ De itt is politikai vitáról volt szó, amelyben az álláspontokat az axiomatikus előfeltevések, értékrendek határozták meg.

A reformközgazdászok mindenesetre a liberális vagy, ahogy akkoriban mondták, „jelző nélküli” piacgazdaság és a „minimális állam” mellett foglaltak állást. ${ }^{13} \mathrm{Az}$

${ }^{9}$ Többen jól ismerték a szociális piacgazdaság elméletét, amelyről egyik külföldről hazatért híve, a miniszterelnök tanácsadója, Hieronymi Ottó jó összefoglalót publikált (Hieronymi [1993]). A liberális táborba tartozó Mihályi Péter pedig részletes kritikát tartalmazó könyvet is írt erről (Mihályi [1989]), mai kifejezéssel politikai marketingnek tekintve a teóriát. Az újabb magyar szakirodalomból lásd Csaba [2014b].

${ }^{10}$ Kornai 1989 előtti kapitalizmusfelfogását részletesen bemutatja Laki [2018].

${ }^{11}$ Tardos Márton még az 1990-es évek közepén is úgy vélte: „nyitottak a viták arról, hogy mi is az állam gazdasági szerepe a piacgazdaságban, és még inkább arról, hogy milyen állami intervenciók tekinthetők kívánatosnak a fejlődő és különösen az alacsony fejlettségi állapotból kitörni vágyó országok esetében." (Tardos [1996] 542. o.)

${ }^{12}$ Az utóbbira utal nemcsak a Surányi Györgytől vett idézet, hanem az SZDSZ-en belüli erős szociálpolitikai orientációjú csoport léte is. Kis János, a párt szellemi vezére egy későbbi tanulmányában magát a „liberális baloldalra” tette. A „jobboldaliakat” - írta - „egyfelől a liberális alapértékek felületes kezelésében, másfelől a piaccal és a magántulajdonnal szembeni kritikátlanságban marasztalom el” (Kis [2000/2014] 378. o.), azaz az egyenlőség és testvériség, valamint az állami szerep háttérbe szorításában. Talán nem tévedünk, ha ezt a bírálatot a „piaci fundamentalista” közgazdászokra vonatkoztatjuk.

${ }^{13}$ A korabeli mondás szerint az előbbi esetben minden megszorító jelző fosztóképző, mint ahogy korábban a „szocialista” hozzátoldás is az volt. 
állam tervgazdaságból ismert formájának jellemzőit pedig hallgatólagosan általánosítottuk minden kormányzatra. Ha a szocializmus nem javítható, az állam pedig összeegyeztethetetlen a piaccal, akkor radikális megoldást kell választani. „Saját bevallásuk szerint a kelet-európai közgazdászok úgy érezték, hogy »belekényszerülnek « a neoliberalizmusba a reformokról a szocializmus alatt szerzett tapasztalataik eredményeként" - állítja Bockman-Eyal [2002/2014] (131-132. o.) több vezető pozícióba került résztvevő önéletírására hivatkozva.

A reformközgazdászok álláspontjának legfőbb elméleti támasza ugyanis az „igazi”, nyugati értelemben vett közgazdaságtan, amit a többség csak akkor kezdett - ha egyáltalán elkezdett - tanulni. A korabeli föáram, az angolszász gyökerü neoliberalizmus ${ }^{14}$ teoretikusan sikere tetőpontjára ért, és gyakorlati eredményei is kezdtek mutatkozni. A „történelem végének” és a washingtoni konszenzusnak az időszakában járunk, amikor a nemzetközi porondon kevesen kérdőjelezték meg a célt és azt, hogy eléréséhez minden országnak ugyanazt az utat kell végigjárnia, ugyanazokat az eszközöket, intézményeket alkalmazva. Mindez alátámasztotta a magabiztosságot, a „nincs alternatíva” Margaret Thatchertől kölcsönzött tézisét. Ezt a receptet ajánlották az európai országok is, amelyekhez föl akarunk zárkózni, a nagy nemzetközi szervezetekkel, főként a Nemzetközi Valutaalappal, az OECD-vel és a Világbankkal karöltve. A „recept” azonban nem azonos az átalakításnak egy jól kidolgozott modelljével, forgatókönyvével - ilyet ugyanis senki nem tudott összeállítani. ${ }^{15}$ Az egyes országoknak volt mozgásterük saját útjuk kialakításához, ${ }^{16}$ és éppen a szilárd keret-rugalmas megvalósítás kettőssége kedvezett a reformközgazdász-szerepnek.

Mennyire ismerték a csoport tagjai ezeket az elméleteket és a belölük levonható gyakorlati tanulságokat? Azaz beszélhetünk-e - Kovács János Mátyás kategóriáját alkalmazva (Kovács [1996]) - utánzásról? Megvolt-e ehhez egyrészt az alap, másrészt a hajlandóság?

A nyitottságot a gyökeres megoldásokra már az előbb említett reformtapasztalatok is megalapozhatják: a felemás, szimulált változtatások nem hozzák meg a várt eredményt. Egy archív dokumentumok, feljegyzések, jegyzőkönyvek elemzésére építő tanulmány szerint ebben alapvető szerepet játszottak a szakma több iskolájának elitjéhez füződő, mindkét fél érdekeit szolgáló nemzetközi kapcsolati hálók, amelyek már sok évtizede épültek. „A kelet-európai reformerek már jóval 1989 előtt a neoliberalizmus követőivé váltak, mint egyfajta transznacionális párbeszéd résztvevői” - írja

\footnotetext{
${ }^{14}$ Ezt a kifejezést a reformközgazdászok közül - hétköznapi tapasztalataik alapján is - többen megbélyegzésnek, „szitokszónak” érzik. Jobb híján mégis ennél maradtam, mert a szakirodalomban, mint az előző idézet is utal rá, a neoliberalizmus elterjedt kategória, a helyette használható monetarizmus szűkebb értelmű, a jelző nélküli liberalizmusnak pedig nagyon sok változata van. A fogalom itt leíró, értékmentes kifejezésként szerepel, amely az 1980-as évektől a fejlett országokban uralkodó gazdaságpolitikai paradigmára utal.

${ }^{15}$ „...e tananyagoknak, sőt a washingtoni konszenzusban összegzett gazdaságpolitikai tudásnak szinte semmi mondanivalója nem volt, nem is lehetett az egyedi történelmi kihívás kezelésére", vagyis a rendszerváltásra - állítja Csaba [2014a] (55. o.). A kelet-közép-európai átalakulás modelltelen volt (Antal [1998] 63. о.).

${ }^{16}$ Lásd erről például Bohle-Greskovits [2012], Csaba [2014b].
} 
Bockman-Eyal [2002/2014] (103. o.). Vagyis szerintük az irányzat már marginális pozícióból is hatást gyakorolt, nem egyszerü utánzásról vagy külső kényszerről volt szó, és a korabeli fóáramú elméletek ismerete sem hiányzott. Sokak számára viszont a felkészültség nagyon gyengének tűnt, a keleti és a nyugati közgazdászok között nemcsak tárgyi tudásban, de a stílusban, a kérdésfeltevésekben, a problémák megközelítési módjában is jelentős volt a különbség. ${ }^{17}$

Kevés az ismeretem ahhoz, hogy ebben a vitában állást foglaljak. Valószínű, hogy a kép nagyon differenciált a reformközgazdászok körében is. Sokan közülük hoszszabb-rövidebb ösztöndíjakkal tanulhattak amerikai, nyugat-európai egyetemeken vagy intézményeknél, néhányan külföldröl, ott szerzett tudományos fokozattal jöttek haza éppen az átalakulás éveiben. Mások kevesebbet tudtak az elméletből, és még kevesebbet a piacgazdaságok tényleges müködéséröl. De a többségre talán jellemző, hogy csak a fóáramú tankönyvekből tanult, empirikus ismeretei a fejlett nyugati gazdaságokról alig voltak - ezért hajlottunk arra, hogy a létező kapitalizmust annak ideáltípusával azonosítsuk. Ez, valamint a már említett fordított hiba, az állam azonosítása annak létező szocialista formájával nem annyira a tárgyi tudás hiányát, mint inkább az elfogultságot, a tudományos elemzés, az alapos mérlegelés hiányát mutatja. Némi mentség, hogy a kritikai társadalomtudomány éppen ekkoriban világszerte apályban volt. ${ }^{18}$

Nem szeretném azt a látszatot kelteni, hogy a kapitalizmus müködésével kapcsolatban mindenki tudatlan vagy naiv volt. Sokan óvtak a túlzott leegyszerüsítésektől. Csak két kiragadott példa. Kornai már a Röpiratban kitért arra, hogy nem akarja idealizálni a magánvállalkozók magatartását általában és különösen nem a korabeli Magyarországon (Kornai [1989] 25-26. o.). Az 1990-es évek közepén Tardos Márton hasonlóképpen fogalmazott: „...a gazdasági szempontból valóban hatékony kapitalizmus nem eszményi társadalom. A kapitalizmusra is legfeljebb az igaz, amit Churchill a parlamentáris demokráciáról állított, azaz »a legrosszabb, kivéve minden más létezőt«. Nem vitatható továbbá az sem, hogy a kapitalizmus távolsága az eszményi rendszertől kialakulásának vad időszakában, így a posztkommunista átalakulás éveiben is még nagyobb, mint általában.” (Tardos [1996] 544-545. o.) Csakhogy mindkét esetben ott áll utána a „de.” Kornai azt feltételezi, hogy a biztonságtudat erősödésével nőnek a magánberuházások, a verseny erősödésével kialakul az igazi tőkés magatartás. Tardos inkább a helyes gazdaságpolitikában bízott, amely a magántulajdont és a magánfelhalmozást ösztönzi, a piacnyitással egy időben az exportot és az importhelyettesítést serkenti, és megteremti az államháztartási egyensúlyt. Ez ugyanis - mint a megfogalmazásból kiolvasható - a privatizáció-liberalizáció-stabilizáció triászának némileg módosított formája, „a felemelkedés egyedül lehetséges útja, amelynek fö vonalaiban a különböző közgazdasági iskolák képviselöi egyetértenek" (uo.). A lényeg tehát a modernizáció, a felzárkózás, amelynek nincsenek alternatív útjai, a nehézségek a jövőben megfelelő feltételek

\footnotetext{
${ }^{17}$ Lásd a Kovács János Mátyás által kezdeményezett vita több hozzászólását (Kovács [1996]). A fenti megfogalmazás Vincze [1996] írásán alapul.

${ }^{18}$ A szociológia helyzetéről lásd Szelényi [2018].
} 
kialakításával enyhíthetők - ami azonban inkább remény, mintsem erre vonatkozó átfogó és részletes program.

Hozzá kell tenni, hogy mint a politikában általában, a gazdaságpolitikában sem illeszkedett minden lépés a teóriához. A kényszerítő körülményeket és az adódó lehetőségeket látva a reformközgazdászok sem maradtak doktrinerek: elgondolásaikba sokszor új, máshonnan vett elemeket is beépítettek. Ennek legjobb példája a köznyelvben mindmáig Bokros-csomagként ismert, nyilvánosan is heterodoxnak nevezett - többek között a „nincs alternatíva” érvével elfogadtatott stabilizációs program, amelynek lényeges összetevői (mint a vámpótlék) ellentétben álltak a föáram felfogásával. ${ }^{19}$

A REFORMKÖZGAZDÁSZOK SZEREPE - A neoliberalizmus mellett az elméletek másik ága, ami már nem az új rendszer működőképességéhez, hanem annak megvalósíthatóságához és ebben az értelmiség szerepéhez kapcsolódik, mindenképpen része az örökségnek, furcsa módon a marxizmus. Bár mindenki szabadulni igyekezett a régi dogmák béklyóitól, ${ }^{20}$ szocializációnk és tanulmányaink nem múltak el nyomtalanul. A marxizmusból is eredeztethető az a meggyőződés, hogy a társadalmi rend alapja a gazdaság, azon belül is meghatározók a tulajdonviszonyok, ezeket kell tehát mielőbb megváltoztatni.

A megvalósítás pedig beilleszthető a társadalommérnökség tágabb, az 1960-as években az Egyesült Államokban és Európában is népszerü fogalomkörébe, ${ }^{21}$ a megtervezett, irányított változtatások közé. Csakhogy ez, különösen az egyéni szabadságra, szerves fejlődésre épülő liberális paradigma esetében, kényes pont - amely a társadalom, a gazdaság tervezését Hayek kifejezésével „végzetes önhittségnek” tartja. Bevezethetö-e a felülről a kapitalizmus? ?2 Bár Bockman-Eyal [2002/2014] szerint az értelmiség feladta a „mérnökösködést”, és a részben politikussá vált közgazdász reformerek úgy vélik, hogy „inkább a gazdaság és a civil társadalom természetes erőinek felszabadítását, az állampolgárok kezdeményezőkészségét és találékonyságát kell elősegíteniük" (134. o.), de azután a gyakorlatból hozott - egyébként orosz - példáik a zárt körben kidolgozott és a nyilvános megvitatást is mellőző gyors végrehajtásról szólnak. ${ }^{23} \mathrm{~A}$ javaslatok egyébként inkább csak egy-egy fontos részterületre - a liberalizálásra, a privatizációra - vonatkoztak, nem jelentettek átfogó és részletes forgatókönyveket. Főként a gyakorlati gazdaságpolitikához közel állók hangsúlyozták, hogy az egyetlen lehetőség a tévedések és próbálkozások (trial and

\footnotetext{
${ }^{19}$ A fő elemekről és hatásokról lásd például Antal [1998]. Antal László később az elfogadtatás fordulatos történetét is leírta (Antal [2000]).

${ }^{20}$ Volt, aki később elismerte, hogy a marxizmus több módszertani megközelítését és tételét ma is érvényesnek tartja, néhányan pedig az újbaloldal szószólói lettek.

${ }^{21}$ Például Tinbergen [1959], Galbraith [1970].

${ }^{22} \mathrm{Ez}$ a nevezetes „kalkulációs vita” kérdésének újabb változata, amely nem a szocializmus müködőképességét, hanem a „tervezett kapitalizmus” működőképességét (vagy legalábbis társadalmi következményeit és gazdasági hatékonyságát) kérdőjelezi meg. A régi vita indításához lásd a Hayek által szerkesztett kötet tanulmányait (Hayek [1935]).

${ }^{23}$ Laki [2000] „az átmenet mérnökeinek” nevezte a Nemzeti Kerekasztal-tárgyalások döntően értelmiségi résztvevőit.
} 
error) módszere, lehetőleg a neoliberális kereten belül maradva (Tardos [1996], Antal [1998]). De ezek a folyamatos korrekciók újabb és újabb részprogramokat követeltek...

Amikor a kérdés Magyarországon felmerült, a válasz egyszerünek látszott: „felülről" csak a jogi-intézményi-szabályozási kereteket alakítják ki, a többi már a piaci erők dolga. De mivel ez a „csak” a változásoknak alapvető dimenziója, amelyben a meghatározó - mint most is kiderült, korántsem semleges - aktor az állam és a politika, maga a válasz sem oldja fel az állami szerepnek a posztszocialista átalakulás során megkerülhetetlen paradoxonát: „A két kiemelkedő feladat végrehajtásának [vagyis az újraelosztás csökkentésének és a privatizációnak - V. É.] van egy fontos - sokak figyelmét elkerülő - sajátossága. Mindkettő a túlsúlyos állam leépítését szolgálja, amit magának a visszaszoruló államnak kell végrehajtania" - írja Tardos [1996] (544. o..). ${ }^{24}$

Ezt az elvi nehézséget háttérbe szorította azonban a közgazdászoknak a szocializmus reformjai során szerzett tapasztalata, amely a szerepillúziók szociológiai háttere: a múltbeli erős pozíció, az intézményi és médiaháttér, a szerepkészlethez kialakított sürü, horizontális és a politika szereplőivel is összekötő kapcsolati háló. Felfogásuk fontos része volt, hogy a tudomány nemcsak az eszközök, hanem a kitüzött célok meghatározásából is részt kérhet - és kaphat. ${ }^{25}$ Ezt erősítette az 1980 -as évek második felében, majd az átalakulás első időszakában a politikai és társadalmi folyamatokra gyakorolt erős befolyás, az aranykor. Mindannyian emlékszünk a demokratikus ellenzék fellépéseire, a „Fordulat és reform” vitáira, a tömegek által nézett beszélgetésekre a televízióban, a százezres példányszámban megjelenő napilapok terjedelmes cikkeire - a társadalom fontosnak tartotta az értelmiséget, és az is fontosnak tarthatta önmagát. „A közép-európai történelemben az értelmiség még soha nem gyakorolt nagyobb kollektív hatalmat, mint a mai Magyarországon” - írta akkoriban Konrád György és Szelényi Iván (Konrád-Szelényi [1992] 10. o.), bár hozzátették, hogy ez könnyen átmenetinek bizonyulhat. Ennek a pezsgésnek sok reformközgazdász is részese volt, mégpedig úgy, hogy egyszerre léphettek fel tudományos tekintéllyel rendelkező kutatóként, politikai tanácsadóként és a közvélemény formálójaként.

Ez a kivételes pozíció részben magyarázatot adhat arra, amit Szelényi Iván joggal vet az értelmiség, köztük a közgazdászok szemére: akkoriban „,a hatalom közelébe kerülő (ha nem is osztályhatalomba jutó) értelmiség [...] többet foglalkozott publicisztikával és politikával, mint kritikai társadalomtudománnyal" (Szelényi [2018] 91. o.). Ritkasággá vált a hátrányok mérlegelése, a létező kapitalizmus szembesítése az ígéretekkel, az esetleges alternatívákkal. A szocializmus kritikai értelmisége, mivel úgy érezte, hogy az új rendszert jórészt ő alkotja meg, a liberális kapitalizmussal szemben elvesztette kritikai attitüdjét. ${ }^{26} \mathrm{Ha}$ a csoporton belülről jelentkezett bírálat, akkor az éppen az elkanyarodást, például a piactorzító állami beavatkozást, a gazdaságon belüli redisztribúció újjáéledését érintette (Karsai [1993], Voszka [1991]).

\footnotetext{
${ }^{24}$ Lásd még ehhez Voszka [1991].

${ }^{25}$ Ennek az álláspontnak régi hagyományai vannak a magyar szakirodalomban is. A maga korában tekintélyes Surányi-Unger Tivadar alaposan érvel a gazdaságpolitika mint tudomány normatív, célmeghatározó jellege mellett (Surányi-Unger [1924]), bírálva Weber [1903/1970] akkoriban már nagy hatású álláspontját.

${ }^{26}$ Ezt hiányolta Szelényi [2018] (84. o.) is, ritka kivételként Szalai Erzsébetet említve.
} 
A lényeges pontokon eltérő véleményekkel szemben viszont nagyon is határozottan léptek fel a reformközgazdászok. Talán használhatjuk itt az „etikai terror” erős kifejezését, amelyet Konrád-Szelényi [1992] (23. o.) általánosságban - nemcsak a hazai viszonyokkal kapcsolatban - felvet: morális alapon gátat lehet vetni a racionális érvelésnek. ${ }^{27}$ Ez megint csak nem a tudományos, hanem a politikai diskurzusok jellemzője. A vitákat általában is inkább a politikai gondolkodásmód vezérelte, amelynek fontos összetevője többek között - Schlett István meghatározása alapján - az, hogy nem megmagyarázni, hanem megváltoztatni akarja a világot, „nem tesz fel kérdéseket az alapvető előfeltevésekre, meggyőződésekből, hitekből indul ki”, megerősítésre és elfogadtatásra, nem pedig bizonyításra irányul (Schlett [2018] 49-52. o.).

A reformközgazdászok előfeltevései, a hitek és remények tehát szilárd alapokra építhettek. A rendszerillúziót táplálta az oszcillációk történeti folyama, a szocializmusbeli átalakítások korlátozott, ezért a gyökeres megoldások felé terelő hatása, az éppen ereje teljében lévő neoliberális elméleti és gazdaságpolitikai föáram, valamint a korlátozott ismeret a kapitalizmus tényleges müködéséről (vagy ennek a tudásnak az értékvezérelt zárójelbe tétele). Az applikációs és szerepillúzió pedig az átalakulás válságos, bizonytalan helyzete által teremtett társadalmi fogadókészségen, a szocializmus idején és a rendszerváltást megelőző években szerzett személyes és csoportélményeken, a „társadalommérnökség”, a hatásgyakorlás lehetőségének tapasztalatán és az erős kapcsolati hálók müködésén alapult. Látszólag minden egy irányba mutat, inkább az szorul magyarázatra, hogy kik és milyen alapokon gondolkozhattak és cselekedhettek másként.

\section{Hogyan müködött? A privatizációs illúzió példája}

A tulajdonosi szerkezet átalakításának kiválasztását nemcsak érdeklődésem és korábbi kutatásaim indokolják, hanem az, hogy a privatizáció a rendszerváltás „lelke”. ${ }^{28}$ Nem véletlen, hogy az átalakulásról és annak illúzióiról folytatott eszmecserék még ma is gyorsan e témához kanyarodnak. ${ }^{29} \mathrm{~A}$ kulcsszerep miatt itt jól tanulmányozhatók a hitek, az előfeltevések és a viták.

A rendszerillúzió ezen a terepen különösen erős volt. A tulajdon a társadalmi-gazdasági berendezkedések szempontjából meghatározó - tanultuk a marxizmusból, Kornai munkáiból, esetleg az akkor Magyarországon még kevésbé ismert tulajdonjogi iskola írásaiból -, a magántulajdon hatékonyabban müködik, mint az állami, és elterjesztésével megfelelö lépések esetén, de mintegy automatikusan versenypiac jön létre. Ám már ennél a széles körben elfogadott kiindulásnál volt egy vitatott

\footnotetext{
${ }^{27}$ Erre utal, hogy az indulatok évtizedek múltán is erősek, lásd az Élet és Irodalomban folytatott vitából Mihályi [2018] és Csillag [2018] hozzászólását, amelyek szerint a liberális irányvonallal szemben álló tábor az „optimális magyar kapitalizmus” híveiből áll, és ebbe a körbe lényegében minden más álláspont besorolható, az állampárttól és Csurkától a szocialistákon át Orbán Viktorig.

${ }^{28}$ „A privatizáció maga a rendszerváltás” - fogalmazott csak kicsi túlzással a cseh Dusan Triska (idézi Estrin [2007] 2. o.).

${ }^{29}$ Lásd a Várhegyi [2018] nyomán kibontakozó vitát az Élet és Irodalom 2018. évi 9-15. számaiban.
} 
pont. Az állami tulajdon leépítése nem azonos a magántulajdon kiterjesztésével, az utóbbi ugyanis elérhető spontán módon, alulról építkezve, új magáncégek alapításával. Ennek szorgalmazása azonban kisebbségben maradt, pedig nem kisebb tekintély, mint Kornai János képviselte a leghatározottabban, részletesen kifejtett érvekkel a nagy visszhangot kiváltott Indulatos röpiratban (Kornai [1989]). ${ }^{30}$

Hasonló álláspontot akkoriban külföldön is kevesen vallottak ${ }^{31}-a z$ állami cégek magánkézbe adása, azaz a szűkebb értelemben vett privatizáció éppen világjelenség volt. A szakirodalomban addigra bőségesen kifejtett átalános indoklást ${ }^{32}$ könnyen át lehetett fordítani az átalakuló országok helyzetére: a privatizáció megoldja a szerkezetváltást és a modernizációt, javítja a versenyképességet, segíti a költségvetési támogatások csökkentését, a pénzügyi egyensúly helyreállítását. A piac erősítése, a magánkézbe adással együtt járó dereguláció és liberalizáció nemcsak az új tulajdonosoknak (a tőkéseknek) jó, hanem az egész társadalomnak: a fogyasztóknak a verseny élénkülése, így az árak csökkenése, a jobb minőség és választék kedvez, az adófizetők pedig elkerülhetik az elvonások emelkedését. Az átmeneti nehézségeket és hátrányokat - mint a munkanélküliség vagy az egyenlőtlenségek növekedését - hosszú távon a növekedés gyorsulása leküzdi, mert a hozadékból mindenki részesedik (az előnyök „lecsorognak”). ${ }^{33}$

A reformközgazdászok így nem álltak egyedül a világban azzal a feltételezéssel, hogy a magánkézbe adás minden baj orvoslására alkalmas elixír. ${ }^{34}$ Ezt a felfogást taktikai megfontolásaik is táplálták. Tanácsadóként ugyanis korábban azt tapasztalták, hogy könnyebb elfogadtatni a javaslatokat, ha a gazdaságnak egy-egy elemét választják ki, amelynek módosítása gyors és látványos sikerrel kecsegtet. A reformereknek csodát kellett ígérniük - ami a politikusok és tanácsadóik közös érdeke -, s eközben maguk is sokszor csodavárók lettek. A rendszerváltás után világossá vált, hogy ebből a szempontból több párt nem müködik másként, mint egy párt: a programok írásának és szükebb körü elfogadtatásának mechanizmusa a korábbihoz hasonló (Voszka [1991]). A parlamenti elfogadtatás persze már más, nehezebb játéktér.

\footnotetext{
${ }^{30}$ Kornai [1989] határozottan ellenezte az áron aluli, „hisztérikusan” sürgetett, „hirtelen operációként” végrehajtott privatizációt. Felfogása szerint az állami tulajdon értékesítése „a hosszan tartó szerves folyamatok közé tartozik" (45. o.). Ennek lezárultáig az állami cégek költségvetési korlátjának keményítését, a szektor szigorú szabályozását, a vállalati önállóság megnyirbálását javasolta. Utóbb némileg módosította álláspontját (Kornai [1990]), de visszaemlékezéseiben azt írja, hogy fö mondanivalója a privatizációval kapcsolatban az elosztásos módszerek elutasítása volt, hiányosságnak csak a külföldi tőke szerepének nem kellő hangsúlyozását tartja, és úgy látja, hogy Magyarországon nem volt gyorsított privatizálás, „az események valóságos menete sokkal közelebb állt ahhoz, amit a Röpirat ajánlott" (Kornai [2005] 362. o.).

${ }^{31}$ Lásd például Murrell-Wang [1993].

${ }^{32}$ A célokról összefoglalóan ír például Aharoni [1986], Yarrow [1986], Savas [1987/1993], VickersWright [1989].

${ }^{33}$ Tardos Márton megfogalmazásával: ha az állami vagyont „a privatizáció és a kárpótlás útján olyan új tulajdonosok kezébe juttatják, akik jól kamatoztatják, akkor mindannyian jól járunk, tehát a társadalom szegényebb rétege is" (Tardos [1991/1999] 277. o.). A munkanélküliséggel kapcsolatban például lehetett azzal érvelni, hogy az elbocsátások növelik a hatékonyságot és a piaci részesedést, ezért távlatilag több munkahely jön majd létre - az állásvesztés hatásait pedig az átképzés, a nagyvonalú segélyezés és a korai nyugdíjazás enyhíti.

${ }^{34}$ Például Aharoni [1986], Toninelli [2000a], Bellini [2000].
} 
A másutt is hangoztatott privatizációs indokokhoz Kelet-Közép-Európában sajátos érvek is hozzáadódtak. A szocializmus elválaszthatatlan részének tekintett állami tulajdon leépítéséhez a politikai és gazdasági szabadság kiteljesedésének reménye kapcsolódott. A privatizáció a várakozások szerint legitimálja az új berendezkedést, és miközben maga is visszafordíthatatlan, a hozzá kapcsolódó erős érdekek révén visszafordíthatatlanná teszi a politikai átalakulást is. Magyarországon lényeges gyakorlati szempont volt az ország fizetésképtelenségének veszélye, ami fontossá tette az eladásból származó bevételeket, továbbá az érintett cégek gyenge piaci-pénzügyi helyzete, ami tulajdonosváltás nélkül tömeges felszámolásokkal fenyegetett, ha a korábban megszokott támogatásokkal források híján - és a szocializmussal való szakítás jegyében, a központi döntések elvi elutasítása miatt - nem lehetett öket életben tartani. Ha pedig közpénzekkel mégis megmentik őket, akkor a pénz kifolyik a lyukas korsóból. A bankok konszolidálása a legnagyobb, de korántsem egyedülálló esetként mutatta: „ameddig nem kerül sor a bankok privatizálására, remény sincs az állami segélyfolyam megállítására" (Várhegyi [2002] 52. o.).

Mindez a tulajdonosi szerkezetet gyors átalakítása és a radikális, széles körre kiterjedő eladások mellett szólt, beleértve a pénzintézetek, a nagyvállalatok, az energetika és a közszolgáltatások zömét. Ehhez adódott, hogy egyrészt a recesszió megakasztásához szerkezetváltásra, tőkeigényes fejlesztésekre van szükség, amire a magyar vállalatok többsége önerőből képtelen; másrészt „,a vállalatok felett felügyeletet gyakorló szervek irányítási képessége annyira meggyöngült, hogy a rendszer amúgy is alacsony fokú müködési hatékonysága nem kis mértékben tovább csökkent" (Tardos [1998] 320. o.). E felfogás szerint az állami cégek hatásos kontrollja, müködésük piaci alapokra helyezése lehetetlen. A külföldi befolyás az átrendezés ütemével kapcsolatban sem maradt el. A nemzetközi szervezetek országrangsoraiban fontos mutató volt a privatizáció sebessége, ${ }^{35}$ és sokszor külföldi üzleti körök is siettették az eladásokat.

Érveket lehetett importálni a fejlett országokból a magánkézbe adás mellett, de teóriákat nem: a kifejezetten a privatizációra vonatkozó elméletek csak utólag formálódtak, amikor már nemcsak Nyugat-Európában, hanem az átalakuló országokban is javában zajlottak a folyamatok. ${ }^{36}$ Még inkább hiányzott a gyakorlati útmutatás a megvalósítás módjára. Az világos volt, hogy a Nyugat-Európában az 1980-as évektöl alkalmazott eljárásokat nem lehet egyszerüen lemásolni, amikor a gazdaság domináns részének magánkézbe adásáról van szó, amely ráadásul pénzügyileg, technológiai és piaci helyzetét nézve gyenge, az egész politikai-gazdasági környezetet szélsőséges bizonytalanság jellemzi, a piaci intézményrendszer pedig jó esetben a privatizációval párhuzamosan (rosszabb esetben azután) épül ki. Ezért a magánkézbe adásnak egy sajátos formájáról van szó, ami később megkülönböztető jelzőt is kapott: rendszerváltó privatizáció. ${ }^{37} \mathrm{~A}$ követhető minta hiánya széles teret nyitott a közgazdászok kreativitásának, és részben felmentést adott a máshol szerzett tapasztalatok (és kritikák) figyelembevétele alól.

\footnotetext{
${ }^{35}$ Lásd például az EBRD évente kiadott Transition Reportjait.

${ }^{36}$ Lásd részletesen Voszka [2018] 282-300. o.

${ }^{37}$ Yarrow-Jasinski [1996a], Sárközy [1997].
} 
Magyarországon sokféle eladási-elosztási módszer került fel a palettára, de közülük kevés volt hungarikum - igazán csak a kárpótlási jegy (és ezt sem a reformközgazdászok találták ki - Mihályi [2010] I. kötet, 192-193. o.). Az innovációban a lengyel és cseh kollégák a kuponos - elosztásos - privatizáció kidolgozásával jobbak voltak, igaz, nemsokára kiderült, hogy Milton Friedman, majd Samuel Brittan, befolyásos kormányzati tanácsadó, illetve publicista néhány rövid napilapcikkben korábban már felvázolta az eljárás alapjait (Friedman [1976/1996]), Brittan [1983/1996]). ${ }^{38}$ A hazai reformközgazdászok többsége az igazi, saját tőkéjüket kockáztató tulajdonosokat pártolta. Az ilyen tulajdonosokat pedig döntően készpénzes, piaci alapú eladások teremthetik meg. Ha ezt a gyors ütemmel is összekapcsoljuk, akkor ebböl egyértelműen a külföldi tulajdonlás nagy súlya adódik, amitől nemcsak tőkét és technológiát, hanem a versenypiaci magatartásminták elterjesztését is vártuk. A szimulált, mesterséges megoldások elvetése a korábbi reformok tapasztalataiból is következett. Ezen az alapon a csoporton belülröl származó korabeli kritika föként az állami jellegü „kvázitulajdonosok” és a vagyon elosztása ellen irányult, azt állítva, hogy a privatizációs illúzió ehhez kapcsolódik: ha a módszert, a tulajdonosok kilétét és az új piacszerkezetet figyelmen kívül hagyjuk, akkor az állami vagyon leépítésétől nem várható valódi versenypiac kialakulása (Voszka [1991]). ${ }^{39}$

Márpedig a módszer döntően befolyásolja az új tulajdonosi szerkezetet, ezért hoszszú távon megszabhatja a társadalmi struktúrát, így a választói támogatás megszerzését szem elött tartó politikai vitáknak is neuralgikus pontja lehet. Az első pártprogramok elemzésekor Laki [2000] arra jutott, hogy a legnagyobb különbség gazdasági téren éppen itt mutatkozik meg: a valódi tőkés tulajdon kialakításával szemben áll a széles tulajdonosi kört preferáló „népi kapitalizmus” és az intézményi tulajdonlás. Tellér [1992/2005] vitairata világosan kimondta a kérdés szoros pártpolitikai beágyazottságát: ha az SZDSZ a régi elit, a menedzsercsoportok érdekeit képviseli, akkor törpepárt lesz, a liberális közép számára a szilárd bázist csak a sok kistulajdonosra, köztük a munkavállalókra építő, esélykiegyenlítő privatizációs stratégia teremtheti meg. A szerzőnek az utóbbi megoldást szorgalmazó álláspontja nem változott (Tellér [1995/2005]), de miután elgondolásai kisebbségbe szorultak, és kilépett a liberális pártból, retorikája ugyancsak átalakult. Úgy vélte, hogy a volt párttársai által képviselt „tulajdonliberalizmus” a „harácsoló tulajdonszerzést” támogatja. A beszédben gúnyosan említett „vezető közgazdászok”, „társadalomfilozófusok” tudatlanságból vagy rosszhiszemüségből a magántulajdont ellenőrzö és hatékony müködésre kényszerítő intézményeket elhanyagolva szerinte a 19. század eleji, „össztársadalmi kontrollal még "meg nem szelídített« tulajdonszerzők és hatalomszerzők" ideológiáját teremtik meg (Tellér [1996/2005] 111. o.). Mások viszont éppen a tulajdonos közvetlen, fizikai részvételére építő, „izzadságszagú” kistulajdont minősítették elavultnak: „Ez teljesen idegen nemcsak a modern, de már a több évszázaddal ezelőtti gazdaság természetétól is." (Antal [1999] 465. o.)

${ }^{38}$ Ezeket az írásokat újra közölte Yarrow-Jasinski [1996b], az ösforrásokat Mihályi [2010] is felidézi.

${ }^{39} \mathrm{Az}$ idézett cikk felvetette, hogy az általa jónak tekintett privatizáció sem csodaszer, nem orvosolja a gazdasági bajokat, de a privatizációs illúziónak ez az általánosabb felfogása nem kapott nagy hangsúlyt. 
Később - érzékelve a társadalmi igényeket és az elindult folyamatokat - a reformközgazdászok mindegyik módszert és az ezzel járó sokszínű szerkezetet is elfogadták (Tardos [1991/1999]), ${ }^{40}$ majd néhány év múlva világosan látták, hogy sem maga a privatizációs folyamat nem makulátlan, sem az új tulajdonosok nem müködnek a várakozásoknak megfelelő módon. A mai kapitalizmust sem feltétlenül a profitmaximalizáló magatartás jellemzi, és az átalakuló országokban még súlyosabbak az ilyenfajta gondok - írta Tardos [1998] (318. o.). Mégis, „....a gazdasági felemelkedés elöfeltétele az üzleti vagyon zömének magánkézbe kerülése, amit azonban csak akkor lehet a társadalom igényeinek megfelelően megvalósítani, ha a magánosításra kerülö állami tőke sorsáról a társadalom konszenzus alapján alakítja ki álláspontját, és ha az eredmény - az ezzel párhuzamosan kibontakozó tulajdonosi magatartás - közelít a már említett tankönyvi követelményekhez." (Uo.) A közelítés reménye megint csak a piacba vetett hiten alapult. „A piac logikája a nem piaci módon létrejött tulajdonosokat is piaci magatartásra kényszeríti, s ha erre nem képesek, kíméletlenül lecseréli. A társadalom igazságérzetét ez természetesen nem elégíti ki, de a gazdaság fejlődése szempontjából mégis ennek a piaci szelekciós mechanizmusnak a müködése a döntő fontosságú." (Vértes-Karsai [1998] 106. o.) Hasonlóképpen vélekedik Antal László: „A gazdasági környezet [...] mindinkább kikényszeríti, hogy azok a tulajdonosok, akik csak kapcsolataiknak vagy éppen a korrupciónak köszönhették vagyonhoz jutásukat, de nem képesek tulajdonukat hatékonyan hasznosítani, előbb-utóbb elveszítsék azt. A sok morálisan megkérdőjelezhető akció végül is versenyképes struktúrát eredményez." (Antal [1999] 465. o.)

A REFORMKÖZGAZDÁszoK SZEREPE • A fenti idézetek már utalnak arra, hogy a "társadalommérnökség” a privatizáció terepén csak korlátozottan érvényesült. A csoport sok tagja nem akarta leállítani az 1990 előtt elindult spontán folyamatokat, ${ }^{41}$ sőt tanácsadóként segítette a vállalatvezetői döntéseket, később pedig bírálta az állam által vezérelt, központosított eladások módszerét. Kornai János - most már a szük értelemben vett, ellenőrzött privatizációt tárgyalva - „a magyarországi privatizálás szélsőséges állami központosítását" hayeki értelemben konstruktivista megoldásnak tekintette, csakúgy, mint a mesterséges, „hivatali irodákban kiagyalt” módszereket, amelyeket Tadeusz Kowalik lengyel közgazdász nyomán „etatista liberalizmusnak" nevezett, és kitartott a spontán erők elsődlegességének érve mellett. Az állam sokféle módszerrel segítheti a magánkézbe adást - írta Kornai [1991] (1027. o.). „De ne kívánják a kormányzatok a magángazdaság szerves növekedésének spontán, decentralizált folyamatát bürokratikus, agyonszabályozott intézkedések tömkelegével és állami tisztviselők túlbuzgó tevékenykedésével helyettesíteni." (Uo.)

\footnotetext{
${ }^{40}$ Sőt a liberális párt 1991-ben javasolta a mindenkinek állampolgári jogon járó, „szerény mértékü” kárpótlást (Tardos [1998] 322. o.). Ebben az időben, már az elindult intézményes privatizációt elemezve Kornai [1991] is elfogadhatónak tartotta - bizonyos feltételek teljesítése mellett - az ingyenes és intézményeket célzó elosztást is.

${ }^{41}$ Igaz, hogy a csoport más tagjai határozottan elítélték a vállalatvezetői tulajdonszerzést, a közvagyon „elherdálását” lehetővé tevő, akkoriban „spontán privatizációnak” nevezett folyamatot (például Bokros [1990]).
} 
Tardos Márton parlamenti képviselőként a „privatizáció privatizációját”, az állami döntések intézményes centralizáltságának leépítését javasolta (Tardos [1991/1999] 274. o.), ami módosított formában, a kisebb cégek egy részénél meg is valósult az önprivatizációnak nevezett konstrukció keretében.

Csakhogy, mint az előbbi szóhasználat is utal rá, egy-egy módszer maga is „konstrukció”. Ezek körvonalazásában, a privatizációs törvények és stratégiák, valamint a pártprogramok, kormányzati intézkedések kidolgozásában a reformközgazdászok folyamatosan részt vettek, tanácsadóként is fontos szerepet játszottak. ${ }^{42}$ Többen nagy, külföldi tulajdonú cégekhez csatlakoztak, vagy kisebb magánvállalkozásokat alapítottak, amelyek - személyes kapcsolatokra is építve - kormányzati szervezetektől és állami cégektől is kaptak megrendeléseket. Sokan állami vállalatok irányító testületeit erősítették, mások időlegesen vagy véglegesen átléptek a politikába és az államapparátusba. Esetenként a privatizációban is döntéshozó pozíciót szereztek. A csoportba tartozók az Állami Vagyonügynökség első igazgatótanácsában - részben a pártok delegáltjaiként - még többségben voltak. ${ }^{43}$ Később arányuk az ilyen testületekben csökkent, de volt, aki néhány évig a privatizáció irányítói közé tartozott. ${ }^{44}$ És mindeközben, ha éppen más szerepet töltöttek is be, folyamatosan írtak az állami vagyon sorsáról és a rendszerváltozás más kérdéseiről tanulmányokat szakfolyóiratokba, cikkeket a napisajtóba, interjúkat adtak, és a kamerák elé álltak - „véleményvezérekként” fontos funkciójuk volt a közvélemény alakításában. Ez egyrészt a klasszikus „forgóajtómódszer”, a politikai és üzleti világ közötti ingázás (Sebők [2019] 174-179. o.), másrészt azonban, mint láttuk, a forgóajtóból ennél több helyen is ki lehetett szállni. Még fontosabb, hogy a szerepek nemcsak váltakoznak, hanem halmozódnak is: egymással párhuzamosan müködtethetők.

Feltételezéseink egy része nem bizonyult illúziónak. Ma is tarthatónak látszik az az álláspont, hogy a tulajdon alapvető rendszer-meghatározó elem, és a magántulajdon kiterjedése, ezen belül a szűkebben vett privatizáció nélkül nem jött volna létre valamiféle kapitalizmus. A magántulajdonba adás számos vonása és következménye bírálható, mint ahogy ezt sokan sokféle indítékból és irányból meg is tették. Lehet jogos a ritka önkritika is (Tömpe [2018]), bár nyilvánvaló, hogy a folyamatokat korántsem kizárólag a reformközgazdászok határozták meg. Most sem látok olyan

${ }^{42}$ Antal László erről a tőle megszokott, rokonszenves nyíltsággal vallott: „Az én szenvedélyem mindig is az volt, hogy a döntéshozók közelében legyek. Nem döntéshozó akartam lenni, de részese, alakítója a folyamatoknak, aki elmondhatja véleményét, s törekedhet a gyakorlati lépések hosszabb távú összefüggésrendszerbe helyezésére", majd keserüen beszélt a feleslegesség érzéséről (Antal [1999] 469. o.). Egyik élményével sem volt, nincs egyedül.

${ }^{43}$ Saját besorolás Mihályi [2010] (298-301. o.) alapján.

${ }^{44}$ Például Matolcsy György 1990-ben az Antall-kormány politikai államtitkára, a Privatizációs Kormánybizottság elnöke volt, Mihályi Péter pedig 1995-1996-ban az ÁPV Rt. igazgatóságának tagja és a szervezet stratégiai ügyvezető igazgatója (lásd Mihályi információgazdag összeállítását: Mihályi [2010] 313-562. о.). 
átfogó, szakmailag kidolgozott és a korabeli politika által is elfogadható elgondolást, amely lényegesen más és egyben reális alternatívát mutatott volna. Ebben leginkább Felcsuti Péterrel értek egyet: „....az adott korlátok között - közéjük értve az ismeretlen terepre lépő döntéshozók ideológiai és szakmai korlátait is, amit egyébként helytől és időtől függetlenül valóban természetesnek tekinthetünk - ez volt a legjobb privatizáció." (Felcsuti [2018])

Három évtized távlatából már az is jól látszik, hogy sok más feltételezésünk a tulajdonosváltással és általában az átalakulással kapcsolatban ábrándkép maradt. Közéjük tartozik, hogy a privatizáció mindent orvosló csodaszer (szelídített formában: a tulajdonosváltás sebessége és a „haladás” üteme között egyirányú kapcsolat van), vagy ha mégsem bizonyul „tankönyvinek”, akkor a piac korrigálja a szerkezet és a müködés hibáit; a versenypiac mintegy automatikusan - a szereplők kilététől és motivációitól függetlenül, illetve azok ellenére, központi szabályozás hiányában is - létrejön; a külföldi befektetők a verseny kialakításának is motorjai lesznek; a magántulajdon mindig hatékonyabb, mint a köztulajdon; vagy hogy az állam és a piac, a politika és a gazdaság szétválasztható, autonóm területek. Ezek közül jó néhányról már annak idején is lehetett volna gyanítani - ha többet tudtunk volna, és készek lettünk volna megkérdőjelezni axiómáinkat -, hogy megalapozatlanok, ellentmondásosak, vagy csak olyan peremfeltételek esetén teljesülhetnek, amelyek létrejötte kevéssé valószínü. Más hitek pedig azért foszlottak szét, mert időközben gyarapodott a tudomány által felhalmozott ismeret, és változott a világ, szükebb és tágabb környezetünk is. Ezeket az elemeket vázolja fel röviden a következő rész.

\section{Amit tudhattunk volna - és amit azóta megtanultunk}

Az ismeretek hiánya az 1980-as és 1990-es évek fordulóján és az azt követő években nem volt abszolút abban az értelemben, hogy ezeket senki sem tudta volna - bár valószínüleg sokunknak voltak komoly hiányosságai. Inkább arról volt szó, hogy a fóáram mellett létező más megközelítéseket nem használtuk, a nagy, liberális vízióba nem illeszkedő elemeket figyelmen kívül hagytuk, nem kezeltük kellő súllyal, következményeiket lekicsinyeltük, vagy elhárításukat a jövőbe utaltuk - pedig a reformközgazdászok véleménye (vagy tépelődésük) legalább befolyásolhatta volna a folyamatokat.

Nem mérlegeltük komolyan, hogy a kapitalizmusnak több formája létezik, és a felzárkózáshoz nem feltétlenül az éppen legfejlettebb országok által bejárt úton lehet eljutni; a modernizációt - vagy általánosabban, az átalakulást - többféle intézményi berendezkedés segítheti. Nem vettük elő Gerschenkron [1962/1984] erről szóló elméletét, pedig az a társadalomkutatók kedvenc olvasmányai közé tarozott a korábbi évtizedekben. Az újabb alternatív elméletek közül hasznos lett volna többek között a közösségi választások teóriájának, a nem marxista politikai gazdaságtannak és az intézményi közgazdaságtannak a kreatív alkalmazása. Mint láttuk, sokan leírták a reformközgazdászok közül is, hogy a létező kapitalizmus nem „tankönyvi" - értsd: a neoklasszikus és neoliberális elméleteknek megfelelö - formában müködik, és ez még kevésbé várható az átalakuló gazdaságokban. Ennek ellenére 
a piac ideáltípusában bíztunk, és nem néztünk szembe azzal, hogy a verseny feltételei maguktól, automatikusan nem alakulnak ki. Ha az új szereplök nem tisztességes versenyben jöttek létre, monopóliumként születtek, vagy azok maradtak, esetleg csak kihasználják az itt és most adódó, éppen a piac hiátusaiból eredő jövedelemszerzési lehetőségeket - beleértve a külföldi tulajdonosokat is -, akkor nem a szabad versengés feltételeinek kialakításában, hanem a számukra kedvezö körülmények fenntartásában lesznek érdekeltek.

Saját tapasztalataink is óvatosságra inthettek volna. „Nem bizonyított az a feltételezés, hogy [...] illúzióból valósággá válik az az 1960-as évek közepe óta élő elgondolás, amely szerint, ha megfelelö formákat alakítunk ki, és ezeket új érdekeltségi viszonyok közé helyezzük, új magatartásminták jönnek létre; áttörve a fennálló hatalmi viszonyokat" - írtuk kicsit túlbonyolítva még az 1980-as évek végén (Szalai és szerzőtársai [1988] 137. o.). Ezt a szocializmusbeli reformokkal, művi megoldásokkal szemben táplált kételyt átfordíthattuk volna a rendszerváltás és az „igazi” privatizáció esetére is: az új formák, szereplők és érdekeltségi viszonyok még a politikai berendezkedés átalakítása után sem feltétlenül vezetnek a cégek viselkedésének gyökeres megváltozásához. Csak ki kellett volna nyitni ifj. Leopold Lajos 1917-ben kiadott könyvének a színlelt kapitalizmusról szóló fejezetét: „...vannak olyan államok, amelyek az összetévesztésig hasonlítanak ugyan a tőkés rendben termelökhöz, csakhogy mégsem termelnek kapitalisztikusan, s ha a jogi kategória kifejlődött is bennük, üres és idegen marad, és gazdasági gyökere alig van. [...] Az a diszparitás terheli, hogy kívülről erőltették, s nem belülről nőtt kifelé. Általa nem az erősebb, hanem az éppen jelen lévő kerekedik felül: aki bírja, marja." (Leopold [1917] 96-97. o.) Feltehettük volna a kérdést, hogy hét évtized múltán nem egy szervetlen, külföldi tőkétől függő gazdaság és az állami szerződésektől, a kormányzat jóindulatától, a központilag elosztott uniós és hazai támogatásoktól függő „,vállalkozó” lesz-e a jellemző, s még inkább azt, hogy mit lehetne ez ellen tenni. Ha igaza volt Antal Lászlónak abban, hogy „[n]em a mindenkori kormányzat politikai szlogenjei döntik el a folyamatokat - bár természetesen hatnak arra -, hanem az önmozgások, amelyeket a gazdaságpolitika vagy felismer, vagy késve és kényszerüen alkalmazkodik azokhoz" (Antal [1999] 465. o.), akkor ez a spontaneitás nem az általa (általunk) kívánatosnak tartott irányba vitt.

Ha viszont az államnak, a gazdaságpolitikának ennél aktívabb szerepet tulajdonítunk, akkor máshol feslik fel a logika, ugyanis elhárítottuk azon neves kutatók, elsősorban a korán induló angol privatizáció tapasztalatait vizsgáló brit közgazdászok figyelmeztetését is, hogy a gazdaság müködése szempontjából nem önmagában a tulajdon a meghatározó, legalább annyira fontos a versenynek kedvező piacszerkezet, a monopóliumok megszüntetése ${ }^{45}$ és az állami szabályozás - amelynek kereteit könnyebb az eladások előtt megteremteni, mint azután, amikor az új szereplők pozíciója már megerősödött (Heald [1985], Yarrow [1986], Savas [1987/1993]). Hallottunk

\footnotetext{
${ }^{45}$ Magyarországon a gazdaság egészét domináló nagyvállalatok részekre bontása mindvégig háttérbe szorult a privatizációs döntésekben, részben az érintett cégvezetők és a külföldi vevők nyomása, részben apparátusi érdekek és a költségvetési bevételek növelésének szempontja miatt (Voszka [2003]). A magánkézbe került monopóliumok szabályozása is gyenge maradt, részben éppen a gyors és sok egyszeri bevételt hozó eladás érdekében.
} 
a piaci kudarcokról, de csak a kormányzati kudarcokra összpontosítottunk, az állam piactorzításától akartunk megszabadulni; az intézményeket ellenőrző, a törvények betartásán őrködő és piacépítő szerepét elhanyagoltuk, azt feltételezve, hogy a nemzetközi verseny elegendő fegyelmező erő.

Nem mentség, de némi magyarázat, hogy ezeknek a megállapításoknak egy része csak később - nem a volt szocialista, hanem a legfejlettebb és a fejlődő országok tapasztalatainak halmozódásával - kapott szilárd elméleti alapokat és nagyobb súlyt a nemzetközi szakirodalomban is. Így szoros a kapcsolat a kérdések második körével, az ismeretek gyarapodásával és a változásokkal.

Az institucionalizmusnak éppen a nagy rendszerek átalakulásáról voltak gyengék a támpontjai. Az 1990-es évek elején az irányzat egyik vezéralakja, Douglas North azt állította, hogy „[a társadalmi rendszerek] visszafordítása nehéz folyamat, amelyről túlságosan keveset tudunk [...], és az intézményi változások dinamikájáról is túlságosan keveset tudunk, és különösen a gazdasági és a politikai piacok kölcsönhatásáról" (North [1992] 75. o.).

A közösségi választások elméletét és a politikai gazdaságtant csak az 1990-es évek közepén kezdték szisztematikusan alkalmazni a tulajdonviszonyok változására. ${ }^{46}$ A kapitalizmus változatainak (varieties of capitalism) Hall és Soskice által kidolgozott alapkerete 2001-ben jelent meg (Hall-Soskice [2001]), és azután vált szinte önálló aldiszciplínává. Az ezredfordulón körvonalazódott határozottabban a neoliberalizmus alternatívája, az állam fejlesztőszerepének újraértékelése, azaz a fóáramtól eltérő fejlödési utak követésének fontossága. Ha-Joon Chang Friedrich List metaforáját felidézve azt állítja, hogy a gazdag országok nemzetközi egyezmények segítségével „kirúgták azt a létrát” elmaradottabb társaik alól, amelyen korábban ők maguk felkapaszkodtak, az iparvédelem, a vámok, az állami támogatások létráját (Chang [2002]). Ezzel egyetértve Justin Yifu Lin, aki a Világbank vezető közgazdásza és alelnöke volt 2008 és 2012 között, nyilvánosan is megfogalmazta véleményét: a washingtoni konszenzus az európai posztszocialista országok átalakulását sem tudta jól vezérelni ( $\mathrm{Lin}$ [2010], [2015]). Mint ezek a példák is sejtetik, ekkortájt a nagy nemzetközi szervezetek álláspontja is módosult, elfogadták az egyes országok erősödő igényének jogosságát sajátos, önálló megoldásokra, vagyis - Grabel [2011] szerint - a „neoliberális koherencia” helyébe egy átmeneti, de "produktív inkoherencia” lépett. ${ }^{47}$

Kiemelt témánknál maradva, ezek az intézmények ma már elismerik, hogy a keletközép-európai privatizáció nem sikertörténet, és ebben az ő tanácsaik is szerepet játszottak, ${ }^{48}$ sőt letesznek a magántulajdon egyoldalú szorgalmazásáról. Az állami vállalatok fontosak a közszolgáltatásokban, a mindennapi életben és az egész gazdaság versenyképességének alakulásában - állítja az OECD [2015] -, ezért az eladás helyett fontosabb irányítási rendszerük javítása, piaci jellegü tevékenységük feltételeinek

\footnotetext{
${ }^{46}$ Lásd például Boyco és szerzőtársai [1996], Shleifer-Vishny [1994], Shleifer [1998].

${ }^{47}$ Ez az elemzés a Valutaalapra vonatkozik. Ricz [2015] a Világbankkal kapcsolatban mutat be hasonló folyamatokat.

${ }^{48}$ A Világbank munkatársának önkritikus hangú elemzése például fontos hiányosságként említi, hogy a verseny szempontja a kelet-közép-európai privatizációban is alárendelt szerepbe szorult, és ezt a nemzetközi szervezetek sem kifogásolták (Nellis [2002]).
} 
megteremtése. Ebben a dinamikus ázsiai, fóként kínai állami társaságok látványos terjeszkedésének tapasztalata mellett szerepet játszhatott, hogy nem sikerült minden kétséget kizáróan bizonyítani a magáncégek hatékonysági előnyét. Pontosabban, a kutatók többségének álláspontja a privatizációs irányzat éppen aktuális erejével együtt ingadozott: az 1980-as években még vegyes eredményre jutottak, később, a fénykorban határozottan a magántulajdon fölényét mutatták ki, majd 2008 után ismét erősödtek a kételyek. ${ }^{49} \mathrm{Mi}$ lehet az ok? Egyetértek Letza és szerzőtársai [2004] megállapításával: a privatizáció elsősorban ideológián, hitek rendszerén alapul, az empirikus elemzéseket is „módszertani torzítás és elöítélet jellemzi”, ami az adatok és esetek kiválasztásában, az üzleti ciklus és a hosszú távú hatások elhanyagolásában, valamint az értékelésben is jelentkezik.

A fenti hivatkozások közül jó néhány a legutóbbi évekből származik, és ez nem véletlen. A 2008. évi válság fontos változásokat hozott az elméletben és a gyakorlatban is: a neoliberalizmus elbizonytalanodásának korábban is érzékelhető jelei most még markánsabbá váltak. ${ }^{50} \mathrm{~A}$ válságkezelés első szakaszának kérészéletű keynesi konszenzusát az elméleti egyetértés tartósnak látszó hiánya váltotta fel, noha volna igény egy új paradigmára. ${ }^{51} \mathrm{~A}$ bizonytalan helyzetben elindult a piac és az állam szerepének átértékelése is. Mintegy kompromisszumként a tudomány és a gazdaságpolitika egyre szélesebb köreiben elfogadottá válik az a korántsem új, de sokáig háttérben hagyott institucionalista-politikai gazdaságtani felfogás, hogy a piacok végső soron politikai konstrukciók; az állam és a piac viszonyára nem az ellentét, hanem a kölcsönös meghatározottság a jellemző. ${ }^{52}$

Gyarapodott a tudásunk az elmúlt három évtized hazai kutatásokban is dokumentált tapasztalataival is: a privatizáció nem panácea, sőt alkalomadtán visszafordítható; a piaci önkorrekció csak nagyon korlátozottan működik, már csak azért is, mert többé-kevésbé tiszta verseny csak egyes részterületeken alakult ki; ennek védelmével és szélesebb körre kiterjesztésével a kormányzat kevésbé foglalkozik, mint annak további torzításával; a tulajdonnal rendelkező, autonóm polgárság gyenge maradt; a politika és a gazdaság összefonódása tartósnak látszik. ${ }^{53}$

A rendszerillúzió és az applikációs illúzió mindennek alapján fokozatosan elbizonytalanodott, és az ezredforduló után, de még inkább a válság hatására elbizonytalanodott maga az elméleti alap, a neoliberalizmus is. De megrendült-e ezt a trendet követve a reformközgazdászok szerepe, kivételezett helyzete is?

${ }^{49}$ Lásd erről részletesen Voszka [2018] 315-323. o.

${ }^{50}$ A tulajdonosi szerkezettel kapcsolatban erre utal az államosítások újraéledése, majd párhuzamos alkalmazása a privatizációval (Voszka [2018]).

${ }^{51}$ Az egyetértés okairól és gyors felbomlásáról lásd Farrell-Quiggin [2012]. Az új paradigma szükségességének indokait részletesen kifejti Csaba [2014b].

${ }_{52}$ Például Polányi [1946/2004], North [1992], Chang [2001], Clift [2014]. Az Élet és Irodalom többször idézett vitájában többen - föként Felcsuti Péter és Csillag István - állítják, hogy a kérdés nem az állami beavatkozás szükségessége; közhely, hogy annak csak a mértéke és a módja vitatott. Lehet, hogy ma már így van, de a rendszerváltás idején, amiről az eszmecsere szól, korántsem ez volt az általánosan elfogadott nézet.

${ }^{53}$ Csak néhány kiragadott példaként lásd Laki Mihály tanulmányait és Szalai Júliával közösen írt könyveit, Szalai Erzsébet, Várhegyi Éva, Mihályi Péter számos publikációját. 
Akik erre a kérdésre igennel válaszolnak, a pozícióvesztést folyamatként írják le, de különböző keretekben. Szalai Erzsébet úgy véli, hogy már az 1980-as évek végén elindult a szerep „önfelszámolása”, ${ }^{44}$ amit a szerző a „köztességre építkező” tevékenység nyílt differenciálódásaként értelmez: képviselőik állami tisztviselők, tanácsadók, kutatók, üzletemberek vagy politikusok lettek (Szalai [1992/1994] 214. o.). Szelényi Iván szerint a reformértelmiség Bildungsbürgertum-projektje ${ }^{55}$ „már 1990-ben elindult a hanyatlás útján[...], végső veresége 1998-ban, illetve 2010-ben következett be" (Szelényi [2018] 99. o.). Itt voltaképpen az osztályhatalom lehetöségének elvesztéséről, a tulajdonos polgárság győzelméről van szó.

Ha a reformközgazdászok szerepét kiindulópontunknak megfelelően ennél szerényebben, a (gazdaság)politika és a közvélemény befolyásolásának képességeként határozzuk meg, akkor a változások kezdetét későbbre tenném, az átalakulást ingadozónak, de végső kimenetében törésszerübbnek látom. A szerepek diverzifikálása nem önfelszámolás, hanem a csoport legfontosabb erősségének (mondhatjuk, társadalmi tőkéjének) megnyilvánulása. Az egyes terepeken szerzett tekintély konvertálható - lehet valaki egy vállalat igazgatóságában a legjobb kutató és a tudósok között a legtöbb gyakorlati ismerettel vagy éppen a legmagasabb beosztással rendelkező tisztségviselő -, a tevékenységek közti határok átjárhatók. Így a szerepek sokszor párhuzamosan jelennek meg, csak az arányuk módosul, a váltás gyakran átmeneti. Részben ennek következménye a megnyilatkozások tartalmának keveredése, a szereptévesztés: a tudós politikusként, a politikus tudósként szólal meg a vitákban. Ugyanakkor ez a helyzet nagy manőverezési teret nyit a résztvevőknek, és lehetővé teszi, hogy a számukra kedvezőtlen időszakokat visszavonulással, egy másik pozícióra váltással átvészeljék. Úgy tünik, hogy a legtöbben ezt a stratégiát követték, és egészen 2010-ig sikerrel. ${ }^{56}$ A kormányváltásokkal (1990-ben és 1998-ban) legfeljebb az értelmiség más szegmensei kerültek elötérbe, amelyek azonban sok ponton érintkeztek a reformközgazdászokkal, nemegyszer abból a körből indulva. Ez utóbbiak számára fennmaradt a befolyás visszaszerzésének esélye, egzisztenciájukat a szerepek közötti váltással megőrizhették, tudományos és médiafórumaik tovább éltek; a csoport mint laza közösség és referenciapont létét sem fenyegette végveszély.

2008 után azonban valami megváltozott. A pénzügyeken messze túllépő válság a kapitalizmus neoliberális változatának müködőképességét kérdőjelezte meg. Eddig úgy tudtuk, hogy az ilyen helyzet az értelmiség aranykora, amely várakozásokat és fogadókészséget teremt új eszméik számára. De ez a krízis különbözött a korábbiaktól. Az 1980-as években készen állt egy tudományosan alátámasztott alternatív nézetrendszer, amely megszabta a célt és a módszert, volt magabiztosság, és volt az értelmiségnek hitele. Mindez 2008 után nemcsak Magyarországon, hanem világszerte megrendült. Nem egyszerủen őrségváltásról, nem is a generációk cseréjéről van szó, hanem a (reform)értelmiség szerepének leértékelődéséről.

\footnotetext{
${ }^{54}$ Ezt az álláspontját a szerző később is fenntartotta (Szalai [2018] 137. o.), bár hozzátette, hogy az értelmiség a Gyurcsány-kormány idején visszanyerte, sőt meg is erősítette befolyását.

${ }^{55}$ A fogalom itt olyan „kulturális polgárságot” jelent, amely a rendszerváltás élcsapata.

${ }^{56}$ Ez természetesen nem mindenkire érvényes egyformán. Volt, aki szerephiányos állapotban tengődött hosszú évekig, mások a szó szoros értelmében belehaltak a feleslegesség érzésébe vagy az elkövetett hibák okozta keserüségbe.
} 
A magyarországi helyzet különlegessége az, hogy itt a válság előbb, már a 2000-es évek közepén nyílttá vált (a folyamatos pénzügyi-egyensúlyi gondok és a neoliberális paradigma kemény vonala felé tájékozódó gazdaságpolitika miatt az elvi alapok is megrendültek), és részben ennek talaján gyorsan kialakult és hatalomra jutott egy új, átfogó politikai vízió. Kívülről úgy látszik, hogy ezt profi politikusok, nem pedig értelmiségiek alakították ki - legfeljebb egy szük körnek jutott az értelmezésben, rendszerré keretezésben szerep (lásd például Tellér [2005]). A „második rendszerváltásnak” nevezett átalakítást sem az értelmiség vezényelte 2010 után. Nem épített a korábbihoz hasonló csapatmunkára a válságkezelés gyakorlata sem - a megoldási módokat néhány politikus jelölte ki és formálta folyamatosan, a kényszerektől és az éppen adódó lehetőségektől függően. Ennek központi alakja, Matolcsy György húsz évvel azelött történetesen a reformközgazdászok körének markáns tagja volt, és most sikerrel alkalmazta a hegemónia létrehozásának a liberális korszakban megtanult módszereit, a forgóajtó-technikától az intézmény- és hálózatépítésig - csak szilárdabb politikai és lényegesen ütőképesebb pénzügyi háttérrel (Sebők [2019]). Ebbe beletartozik a saját szak-, média-, sőt müvészértelmiség kinevelése és megerősítése is, kormányzati támogatással, új szervezetek alapításával; ebben a Matolcsy vezette jegybank alapítványai is tevékenyen részt vettek.

Csakhogy ennek a szellemi holdudvarnak a kormányzat valószínüleg más szerepet szán, mint amit a régiek betöltöttek, vagy legalábbis az egyes tevékenységtípusok arányai lényegesen eltolódnak. Az értelmiség célmeghatározó és a végrehajtásban is alapvető szerepe már a rendszer indulásakor megkérdőjeleződött, a politika vitathatatlanul dominánssá vált. Elég erős lett ahhoz, hogy a tanácsadókat ne követnie kelljen, hanem felhasználhassa őket saját céljainak elérése érdekében. A konszolidált periódusok és kormányaik - s ma Magyarországon ez a helyzet - leértékelik az értelmiséget, esetleg tartanak a társadalmilag és kulturálisan tőlük különböző csoport bírálatától. ${ }^{57} \mathrm{Az}$ új vonásokat öltő politikának elsősorban lojális végrehajtókra, a legitimáció feladatának elvégzésére, az elhatározott-megtett lépések népszerűsítésére van szüksége - a spindoktorság, a marketing és a PR válik fontossá. Felismerve, hogy befolyást leginkább ilyen szerepekben lehet gyakorolni, a tudomány köréből induló hívek közül néhányan átlépnek ezekre a terepekre, nagy csoportok viszont többé-kevésbé eltávolodnak korábbi politikai otthonuktól, annak kritikusaivá válnak. ${ }^{58}$ A tudomány fügefalevélként is felesleges lett, nem kutatók kellenek, hanem harcosok. És a kereslet - mint a megmaradó többség és a felnövekvő új generáció útja mutatja - most is megteremti a kínálatot.

Mindennek következtében a politikához közel álló, azt alapvető kérdésekben befolyásoló reformértelmiségi csoportoknak nemcsak az összetétele változott meg az utóbbi években, hanem, úgy tünik, magának a szerepnek a létalapjai vannak megszünőben. A szerephez kötődő korábbi feltételezések önmagukban nem nevezhetők illúziónak: a hatásgyakorlás a kör számos tagja számára sokáig mindennapi tapasztalat

${ }^{57}$ Szalai [2018] részletesen bemutatja ezt a folyamatot, többek között azt állítva, hogy a félelem az egyik fö oka az értelmiség háttérbe szorításának (126-155. o.).

${ }^{58}$ Az előbbire példa G. Fodor Gábor, az utóbbira a Jakab-Urbán [2017] által szerkesztett tanulmánykötet több szerzője vagy a hosszú sor Bod Péter Ákostól Chikán Attilán át Mellár Tamásig. 
volt, amire ma is büszkeséggel tekintenek. Illúziónak csak a tartósság bizonyult, az a hit, hogy ez akármeddig fennmaradhat.

A szerepvesztés pedig szélesebb kört érint, mint a neoliberális rendszert képviselö, a paradigma elbizonytalanodása és a politika irányváltása miatt diszkreditált reformközgazdászokat, akik számára a politikai befolyásolás lehetősége végképp bezárulni látszik. Ezt a közvélemény befolyásolásával is kevéssé kompenzálhatják, részint a megjelenési felületek összeszükülése miatt, de azért is, mert a társadalom szemében is aláásta hitelességüket a kritikai megközelítés hiánya és korábbi szoros kapcsolatuk a politikával. Így fásultan vagy éppen a dolgok menetével elégedetten a nagyközönség sem tart igényt véleményükre, amelyet sokszor - és nem alaptalanul - a háttérbe szorítottak elfogultságának tulajdonít.

\section{Merre tovább?}

Ha igaz, hogy a sajátos magyar körülmények miatt szokatlanul gyorsan és radikálisan meg kell válnunk a régi szereptől, akkor annak alapjellemzőjét, az összetettséget feladva dönteni kell. A mit siratunk azonban, az most is erőforrás: van választási lehetőség, csak a korábbinál sokkal kisebb. A reformközgazdászok számára az államapparátusi karrier szinte lehetetlen, a politikussá vagy tanácsadóvá válás keskeny ösvénynyé szükült, a perifériára szorított ellenzéki pártok egy részére korlátozódik. Az üzleti élet, a szerény keretekben müködő vállalkozások terepe még nyitva áll, és - már csak generációs okokból is - a teljes visszavonulás sem kizárt.

Ezeken kívül két lehetőséget látok. Aki nem tud letenni a politika befolyásolásáról, az felveheti a kesztyüt, maga is harcossá válhat - persze csak partizánként, erős háttér nélkül. Idetartozik a vállaltan elfogult publicisztika, amit azonban a szerepek tisztázása jegyében érdemes lenne élesen elválasztani más tevékenységektől, elsősorban a tudománytól. Ez azt feltételezi, hogy a szerző szakmai tekintélyét nem használja politikai álláspontjának támaszaként, nyíltan kimondva, hogy itt és most más nézöpontról van szó, és megfordítva: tudományos írásaiba nem szüremlik be politikai meggyőződése.

Az alternatív megoldás ugyanis éppen ez: a visszatérés az eredeti kutatói szerephez. Az egyik ág a kritikai társadalomtudomány, amelynek lényege az illetékesség visszaszerzése a nagy társadalmi kérdések megválaszolására, valamint az értelmező reflexivitás, az immanens rendszerkritika. Ez „,nem válaszokat, megoldásokat keres, hanem kérdéseket vet fel, és ha eredményes, akkor kételyt támaszt az olvasóban korábban megkérdőjelezhetetlennek gondolt ítéleteit illetően [...] a létező posztkommunista kapitalizmusokat a saját ígéreteivel és lehetőségeivel szembesítve teszi fel a kérdést: biztos, hogy nem lehetne másként csinálni?” - írja Szelényi Iván (Szelényi [2018] 30. o., 84. o.), aki szerint a jelenlegi magyar helyzet ehhez sok muníciót ad: most érdemes csak igazán kritikai társadalomtudományt müvelni! Ehhez egyelöre legalább az elemi feltételek adottak.

A másik ág a Max Weber-i értelemben vett tiszta tudomány, „a tudomány mint hivatás" választása, amely nem befolyásra törekszik, nem értékel, hanem értelmez. „Értékmentes”, elfogulatlan elemzést kíván, megpróbálva kívül tartani vagy legalábbis élesen elválasztani ettől a személyes meggyőződéseket, hiteket, értékítéleteket, 
amelyek között természetesen a kutatónak és az olvasónak is választania kell, de „a legkevésbé a mi szigorúan empirikus tudományunk vindikálhatja magának azt a szerepet, hogy megtakarítsa ezt a választást az egyes embernek, s nem is szabad felkeltenie azt a látszatot, hogy képes rá” (Weber [1917/1970] 94. o.).

A tudomány bármelyik ága melletti döntés azt jelenti, hogy szükségből erényt kovácsolunk: ha a politika nem tart igényt a reformközgazdászok szolgálataira, ezt nem veszteségként, hanem szabadságként és lehetőségként érdemes felfogni. Csak a politikai ambícióktól, a „pártfegyelemtől”, a törzsi szekértábor-mentalitástól kellene megszabadulni, a társadalommérnöki szerepet kellene átértékelni. Ez persze nem könnyü.

\section{Hivatkozások}

Aharoni, Y. [1986]: The Evolution and Management of State-Owned Enterprises. Ballinger, Melrose.

Antal László [1998]: Az átmenet évtizede. Kormányok, programok, gazdasági folyamatok. Megjelent: Kurtán Sándor-Sándor Péter-Vass László (szerk.): Magyarország évtizedkönyve. A rendszerváltás (1988-1998). Demokrácia Kutatások Magyar Központja Alapítvány, Budapest, 57-81. o.

AnTAL LÁszLó [1999]: „Nem tudták, de tették.” Karsai Gábor interjúja. Közgazdasági Szemle, 46. évf. 5. sz. 462-469. o.

Antal LÁszló [2000]: A Bokros-csomag. Beszélő, 5. évf. 6. sz. 82-91. o.

Bellini, N. [2000]: The Decline of State-Owned Enterprise and the New Foundations of the State-Industry Relationship. Megjelent: Toninelli (szerk.) [2000b] 25-48. o. https://doi. org/10.1017/cbo9780511896798.003.

Bockman, J.-EyaL, G. [2002/2014]: Kelet-Európa mint a közgazdaságtani tudás laboratóriuma. A neoliberalizmus transznacionális gyökerei. Fordulat 21, http://fordulat.net/pdf/21/ F21_Bockman-Eyal.pdf.

BoD PÉTer Ákos [2006]: A szociális piacgazdaság Antall József kormányzati programjában és kormánya gyakorlatában. Megjelent: Jeszenszky Géza-Kapronczay Károly-Biernaczky Szilárd (szerk.): A politikus Antall József - az európai úton. Mundus, Budapest, 22-42. o.

Bohle, D.-Greskovits Béla [2012]: Capitalist Diversity on Europe’s Periphery. Cornell University Press, New York.

BoKros Lajos [1990]: Rendszerváltás vakvágányon. 1989. Kísérlet a társadalmi tulajdon elherdálására. Megjelent: Kurtán Sándor-Sándor Péter-Vass László (szerk.): Magyarország Politikai Évkönyve, 1989. Aula-OMIKK, Budapest, 72-78. o.

Boyco, M.-Shleifer, A.-Vishny, R. [1996]: A Theory of Privatization. The Economic Journal, Vol. 106. No. 435. 309-319. o. https://doi.org/10.2307/2235248.

Brittan, S. [1983/1996]: Privatization: A New Approach. Megjelent: Yarrow-Jasinski [1996b] 423-426. o. https://doi.org/10.25291/vr/1983-1-vr-423.

BunCE, V.-CsanÁdi MÁria [1993]: A bizonytalanság szerepe az átmenetben. A posztkommunizmus néhány sajátossága Magyarország példáján. Közgazdasági Szemle, 40. évf. 1. sz. 32-51. o.

Chang, H.-J. [2001]: Breaking the Mould. An Institutionalist Political Economy Alternative to the Neoliberal Theory of the Market and the State. Social Policy and Development Programme Paper, No. 6. 
Chang, H.-J. [2002]: Kicking Away the Ladder: Development Strategy in Historical Perspective. Anthem Press, London, https://doi.org/10.1108/10748120510618222.

Clift, B. [2014]: Comparative Political Economy. States, Markets and Global Capitalism. Palgrave Macmillan, London, https://doi.org/10.1007/978-1-137-40600-2.

Csaba LÁszló [2014a]: Átmenettan és közgazdaságtan. Módszertani tanulságok egy részterület műveléséből. Közgazdasági Szemle, 61. évf. 1. sz. 53-67. o.

CsAbA LÁszló [2014b]: Európai közgazdaságtan. Akadémiai Kiadó, Budapest.

Csillag István [2018]: A cifra szolga. Élet és Irodalom, 62. évf. 14. sz.

Estrin, S. [2007]: The Impact of Privatization in Transition Economies. Article for the New Palgrave Dictionary of Economics. 2. kiadás, School of Economics and Political Science, London.

FArrell, H.-Quiggin, J. [2012]: Consensus, Dissensus and Economic Ideas: The Rise and Fall of Keynesianism during the Economic Crisis and the Rise and Fall of Keynesianism. International Studies Quarterly, Vol. 61. No. 2. 269-283. o. https://doi.org/10.1093/isq/sqx010.

Felcsuti Péter [2018]: A megszólítás okán. Élet és Irodalom, 62. évf. 15. sz.

Friedman, M. [1962/1966]: Kapitalizmus és szabadság. Akadémiai Kiadó, Budapest.

Friedman, M. [1976/1996]: How to Denationalize. Megjelent: Yarrow-Jasinski (szerk.) [1996b] 421-422. o.

Galbraith, J. K. [1970]: Az új ipari állam. Közgazdasági és Jogi Könyvkiadó, Budapest.

Gerschenkron, A. [1962/1984]: A gazdasági elmaradottság történelmi távlatból. Gondolat, Budapest.

Grabel, I. [2011]: Not Your Grandfather's IMF: Global Crisis, 'Productive Incoherence' and Developmental Policy Space. Cambridge Journal of Economics, Vol. 35. No. 5. 805-830. o. https://doi.org/10.1093/cje/ber012.

Hall, P. A. [1993]: Policy Paradigms, Social Learning, and the State: The Case of Economic Policymaking in Britain. Comparative Politics, Vol. 25. No. 3. 275-296. o. https://doi. org/10.2307/422246.

Hall, P. A.-Soskice, D. [2001]: Varieties of Capitalism. The Institutional Foundations of Comparative Advantage. Oxford University Press, Oxford, https://doi.org/10.1093/01992 47757.001.0001.

Hayek, F. A. (szerk.) [1935]: Collectivist Economic Planning. Lowe and Brydone, London.

Heald, D. [1985]: Will the Privatization of Public Enterprises Solve the Problem of Control? Public Administration, Vol. 63. No. 1. 7-22. o. https://doi.org/10.1111/j.1467-9299.1985. tb00582.x.

Hieronymi Otтó [1993]: A szociális piacgazdaság és a magyar átalakulás, Magyar Szemle, Új folyam, 2.évf. 7. sz.693-713. o. http://www.magyarszemle.hu/cikk/a_szocialis_piacgazdasag_ es_a_magyar_atalakulas.

Hirschman, A. [1982]: Shifting Involvements: Private Interest and Public Action. Blackwell, Oxford.

JAKAB ANDRÁs-URbÁN LÁszló (szerk.) [2017]: Hegymenet. Társadalmi és politikai kihívások Magyarországon. Osiris Kiadó, Budapest.

KARSAI Judit [1993]: Fedőneve: reorganizáció. Közgazdasági Szemle, 40. évf. 9. sz. 788-801. o. KeYnes, J. M. [1936/1965]: A foglalkoztatás, a kamat és a pénz általános elmélete. Közgazdasági és Jogi Könyvkiadó, Budapest.

KIs JÁNos [2000/2014]: Liberalizmus Magyarországon - tíz évvel a rendszerváltás után. Megjelent: Mi a liberalizmus? Esszék, tanulmányok, 1985-2014. Pesti Kalligram, Budapest, 361-388. o. 
KONRÁD GYÖRGY-SZELÉNYI IVÁN [1992]: Értelmiség és dominancia a posztkommunista társadalmakban. Politikatudományi Szemle, 1. évf. 1. sz. 9-28. o.

Kornai János [1957]: A gazdasági vezetés túlzott központosítása. Közgazdasági és Jogi Könyvkiadó, Budapest.

Kornai János [1980]: A hiány. Közgazdasági és Jogi Könyvkiadó, Budapest.

Kornai JÁnos [1983]: Bürokratikus és piaci koordináció. Közgazdasági Szemle, 30. évf. 9. SZ. 1025-1038. O.

KORNAI JánOs [1989]: Indulatos röpirat, a gazdasági átmenet ügyében. HVG Kiadó, Budapest.

Kornai János [1990]: Kiegészítések a „Röpirathoz”. Közgazdasági Szemle, 37. évf. 7-8. sz. 769-793. o.

Kornai JánOs [1991]: A privatizáció elvei Kelet-Európában. Közgazdasági Szemle, 38. évf. 11. sz. 1021-1040. o.

Kornai János [1993]: A szocialista rendszer. HVG Kiadó, Budapest.

Kornai János [1998]: Szocializmusból a kapitalizmusba. Mit jelent a rendszerváltás? Megjelent: Kurtán Sándor-Sándor Péter-Vass László (szerk.): Magyarország évtizedkönyve. I. kötet. A rendszerváltás (1988-1998). Demokrácia Kutatások Magyar Központja Alapítvány, Budapest, http://www.politikaievkonyv.hu/online/mp10.

Kornai János [2005]: A gondolat erejével. Rendhagyó önéletrajz. Osiris Kiadó, Budapest. KovÁcs JÁNos MÁTYÁs [1996]: Örökség - utánzás - felfedezés. Közgazdasági gondolkodás Magyarországon 1989 után. Töprengés leltár közben. Közgazdasági Szemle, 43. évf. 4. sz. 321-362. o.

Krugman, P. [1995]: Dutch tulips and emerging markets. Foreign Affairs, Vol. 74. No. 4. 28-44. o. https://doi.org/10.2307/20047206.

LAKi MiнÁLY [2000]: Az ellenzéki pártok gazdasági elképzelései 1989-ben. Közgazdasági Szemle, 47. évf. 3. sz. 230-249. o.

LAKi MıнÁLy [2018]: Kornai János a kapitalizmusról, 1953-1989. Korall, 19. évf. 72. sz. 117-136. o.

LEOPOLd LAJOs, IfJ. [1917]: Elmélet nélkül. Benkő Gyula cs. és kir. udvari könyvkereskedése, Budapest.

Letza, S. R.-Smallman, C.-Sun, X. [2004]: Reframing privatisation: Deconstructing the myth of efficiency. Policy Sciences, Vol 37. No. 2. 159-183. o. https://doi.org/10.1023/ b:olic.0000048530.30139.98.

LIN, J. [2010]: New Structural Economics. A Framework for Rethinking Development. World Bank Policy Research Working Paper, No. 5197.

Lin, J. [2015]: The Washington Consensus revisited: a new structural economics perspective. Journal of Economic Policy Reform, Vol. 18. No. 2. 96-113. o. https://doi.org/10.1080/174 87870.2014.936439.

Mihályi PÉTER [1989]: Az NSZK gazdaságpolitikája - elmélet és gyakorlat. Kossuth Könyvkiadó, Budapest.

Mihályi Péter [2010]: A magyar privatizáció krónikája. Pannon Egyetem-MTA Közgazdasági Intézet, Budapest.

Mihályi PÉTER [2015]: A privatizált vagyon visszaállamosítása Magyarországon, 2010-2014. MTA KRTK Mühelytanulmányok, MTDP No. 7.

Mihályi PÉTer [2018]: Utólagos értékelés. Élet és Irodalom, 62. évf. 12. sz.

Murrell, P.-WAng, Y. [1993]: When privatization should be delayed. The effect of communist legacies on organizational and institutional reforms. Journal of Comparative Economics, Vol. 17. No. 2. 386-406. o. https://doi.org/10.1006/jcec.1993.1031. 
Nellis, J. [2002]: The World Bank, Privatization and Enterprise Reform in Transition Economies. A Retrospective Analysis. The World Bank, Washington, DC, http://www-wds. worldbank.org/external/default/WDSContentServer/WDSP/IB/2002/03/22/000094946_ 02030804050325/Rendered/PDF/multi0page.pdf.

North, D. C. [1992]: Institutions and Economic Theory. The American Economist, Vol. 61. No. 1. 72-76. o. https://doi.org/10.1177/0569434516630194.

OECD [2015]: OECD Guidelines on Corporate Governance of State Owned Enterprises. OECD Publishing, Párizs.

PolÁNyi KÁROLY [1946/2004]: A nagy átalakulás. Korunk gazdasági és politikai gyökerei. Napvilág Kiadó, Budapest.

RICz Judit [2015]: Fejlesztő állam: egy letűnt világ nyomában (?). MTA Közgazdaság- és Regionális Tudományi Kutatóközpont Világgazdasági Intézet, Mühelytanulmányok, 108. sz.

RöPKE, W. [1943]: A harmadik út. Korunk társadalmi válsága. Aurora, Budapest.

SÁRKözy TAMÁs [1997]: Rendszerváltozás és a privatizáció joga. Magyar Tudományos Akadémia, Budapest.

SAVAS, E. S. [1987/1993]: Privatizáció. Hogyan vonuljon ki az állam a gazdaságból? Akadémiai Kiadó, Budapest.

Schlett István [2018]: Appendix. A politikai gondolkodás története Magyarországon. Századvég Kiadó, Budapest.

SEвőк MikLós [2019]: Paradigmák fogságában. Elitek és ideológiák a magyar pénzügyi kapitalizmusban. Napvilág Kiadó, Budapest.

Shleifer, A. [1998]: State versus Private Ownership. NBER Working Paper series, No. 6665. https://doi.org/10.3386/w6665.

Shleifer, A.-Vishny, R. [1994]: Politicians and Firms. The Quarterly Journal of Economics, Vol. 109. No. 4. 995-1025. o. https://doi.org/10.2307/2118354.

SURÁNYI GYÖRGY [2019]: Válságok után, tragédiák árnyékában. Megjelent: Gombár 80. Egy emelt fejü republikánus. Magánkiadás. 81-86. o.

SuráNyi-Unger Tivadar [1924]: A célkitűzés problémája a gazdaságpolitikában, különös tekintettel a kereskedelmi politikára. Különlenyomat a Közgazdasági Szemléből, Budapest.

Szalai Erzsébet [1992/1994]: A reformközgazdászok metamorfózisa. Megjelent: Szalai [1994] 211-216. o.

SzALAI ERzsÉBET (1993/1994]: Technokraták, kliensek, yuppie-k. A gazdasági elit szerkezete és viselkedése. Megjelent: Szalai [1994] 201-208. o.

SzALAi ERzsÉBEт [1994]: Útelágazás. Hatalom és értelmiség az államszocializmus után. Pesti Szalon Könyvkiadó-Savaria University Press, Budapest-Szombathely.

Szalai Erzsébet [2018]: Hatalom és értelmiség a globális térben. Tanulmányok és publicisztikai írások, 2015-2018. Kalligram Kiadó, Budapest.

Szalai Erzsébet-Várhegy Éva-Voszka Éva [1988]: Lehet-e (tulajdon)reformot csinálni, s ha igen, milyet? Megjelent: Lengyel László (szerk.): Tulajdonreform. Pénzügykutató Rt., 135-138. o.

SzELÉNyi Iván [1992]: Harmadik út? Polgárosodás a vidéki Magyarországon. Akadémiai Kiadó, Budapest.

SZELÉNyi Iván [1995/1998]: A posztkommunista társadalom szerkezetének változásai. Akadémiai székfoglaló. 1995. január 25. Megjelent: Értekezések és emlékezések. Akadémiai Kiadó, Budapest, https://core.ac.uk/download/pdf/79466882.pdf. 
SZELÉNYi Iván [2018]: Tanulmányok az illiberális posztkommunista kapitalizmusról, 20142018. Corvina Kiadó, Budapest.

TARdos Márton [1991/1999]: Miért szükséges és hogyan lehetséges az állami tulajdon felszámolása. Megjelent: A liberális reformer. Válogatás a 70 éves Tardos Márton írásaiból. Pénzügykutató-Perfekt, Budapest.

TARdos Márton [1996]: Gondolatok a posztkommunista transzformáció és a közgazdaságtudomány kapcsolatáról. Közgazdasági Szemle, 43. évf. 6. sz. 541-563. o. http://www. kszemle.hu/tartalom/cikk.php?id=1025.

TARdos MÁrton [1998]: Sikeres-e a privatizáció? Magyarországi tapasztalatok (1990-1997). Közgazdasági Szemle, 45. évf. 4. sz. 317-332. o. http://www.kszemle.hu/tartalom/cikk. php?id=512.

Tellér Gyula [1992/2005]: Döntés elött. Politikai vitairat a Szabad Demokraták Szövetsége 1992. novemberi küldöttgyülése elé. Megjelent: Tellér [2005] 181-194. o.

Tellér Gyula [1995/2005]: Egy feltartóztathatatlan folyamat. Megjelent: Tellér [2005] 85-101. o.

Tellér Gyula [1996/2005]: A liberális tulajdonideológia. A Dies Academicus 1996. február 16-i rendezvényén elhangzott előadás szerkesztett változata. Megjelent: Tellér [2005] 108-113. o.

Tellér Gyula [2005]: A rendszerváltás rendszere. Cikkek, esszék, elemzések. Kairosz Kiadó, Budapest.

Tinbergen, J. [1959]: The Theory of the Optimum Regime. Megjelent: Fox, K. A.-Sengupta, J. K.-Narasimham, G. V. L. (szerk.): Economic Models, Estimation and Risk Programming: Essays in Honor of Gerhard Tintner. Lecture Notes in Operations Research and Mathematical Economics. Vol. 15. Springer, Berlin-Heidelberg.

Toninelli, P. A. [2000a]: The Rise and Fall of State-Owned Enterprise. The Framework. Megjelent: Toninelli (szerk.) [2000b] 3-24. o.

Toninelli, P. A. (szerk.) [2000b]: The Rise and Fall of State-Owned Enterprise in the Western World. Cambridge University Press, Cambridge.

Tömpe István [2018]: Sikeres privatizáció? Élet és Irodalom, 62. évf. 14. sz.

VÁRHegyi Éva [2002]: Bankvilág Magyarországon. Helikon Kiadó, Budapest.

VÁrHegy I Éva [2018]: Illúziók bűvöletében. Élet és Irodalom, 62. évf. 9. sz.

VÉRTES ANDRÁs-KARSAI GÁBOR [1998]: Gazdasági átalakulás és gazdaságpolitika. Megjelent: Kurtán Sándor-Sándor Péter-Vass László (szerk.): Magyarország évtizedkönyve. I. kötet. Demokrácia Kutatások Magyar Központja Alapítvány, Budapest, 102-115. o. http://www. politikaievkonyv.hu/online/mp10.

Vickers, J.-Wright, V. (szerk). [1989]: The politics of privatisation in Western Europe. Frank Cass, London.

VinCze János [1996]: Van-e magyar út az elméleti közgazdaságtanban? Közgazdasági Szemle, 43. évf. 4. sz. 331-335. o. http://epa.oszk.hu/00000/00017/00015/pdf/EPA00017_ kozgazdasagi_szemle_1996_04_331-335.pdf.

Voszka Éva [1991]: Privatizációs illúziók. Társadalmi Szemle, 42. évf. 12. sz. 21-29. o.

Voszka Éva [2003]: Versenyteremtés - alkuval. Akadémiai Kiadó, Budapest.

VoszKa Éva [2018]: Az állami tulajdon pillanatai. Gazdaságtörténeti és tudománytörténeti nézőpontok. Akadémiai Kiadó, Budapest.

WeBer, M. [1903/1970]: A társadalomtudományi és társadalompolitikai megismerés „objektivitása”. Megjelent: Állam, politika, tudomány. Tanulmányok. Közgazdasági és Jogi Könyvkiadó, Budapest, 9-73. o. 
Weber, M. [1917/1970]: A szociológiai és közgazdasági tudományok „értékmentességének” értelme. Megjelent: Állam, politika, tudomány. Tanulmányok. Közgazdasági és Jogi Könyvkiadó, Budapest, 74-125. o.

Yarrow, G. [1986]: Privatization in theory and practice. Economic Policy, Vol. 32. No. 1. 323-377. o. https://doi.org/10.2307/1344560.

Yarrow, G.-Jasinski, P. [1996a]: Privatization: An Overview of the Issues. Megjelent: Yarrow-Jasinski (szerk.) [1996b] 1-48. o.

Yarrow, G.-Jasinski, P. (szerk.) [1996b]: Privatization. Critical Perspectives on the World Economy. Routledge, London-New York. 